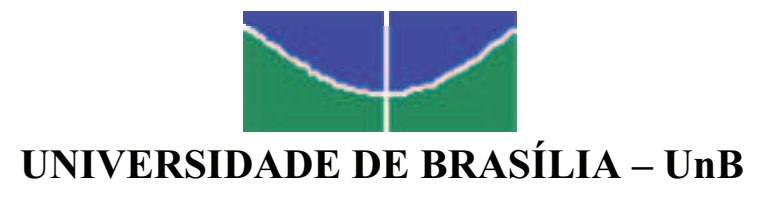

FACULDADE DE ECONOMIA, ADMINISTRAÇÃO, CONTABILIDADE E CIÊNCIA DA INFORMAÇÃO E DOCUMENTAÇÃO (FACE) PROGRAMA DE PÓS-GRADUAÇÃO EM ADMINISTRAÇÃO (PPGA) CURSO DE ESPECIALIZAÇÃO EM DESENVOLVIMENTO GERENCIAL

ALICE MARIA FALQUETTO LINDALVA LIMA COSTA

\footnotetext{
AVALIAÇÃO DE IMPACTO EM PROFUNDIDADE: CURSO DE DESENVOLVIMENTO GERENCIAL DE UMA IFES
} 
ALICE MARIA FALQUETTO

LINDALVA LIMA COSTA

\section{AVALIAÇÃO DE IMPACTO EM PROFUNDIDADE: CURSO DE DESENVOLVIMENTO GERENCIAL DE UMA IFES}

Monografia apresentada ao Programa de Pós-Graduação em Administração da Faculdade de Economia, Administração, Contabilidade e Ciências da Informação e Documentação (FACE), da Universidade de Brasília, como requisito parcial à obtenção do grau de Especialista em Desenvolvimento Gerencial.

Orientadora: $\operatorname{Prof}^{\mathrm{a}} \mathrm{Dr}^{\mathrm{a}}$ Catarina Cecília Odelius

Brasília - DF 


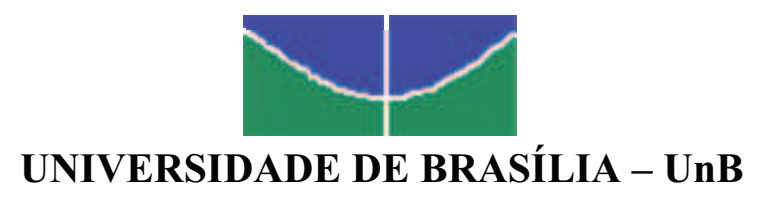

FACULDADE DE ECONOMIA, ADMINISTRAÇÃO, CONTABILIDADE E CIÊNCIA DA INFORMAÇÃO E DOCUMENTAÇÃO (FACE) PROGRAMA DE PÓS-GRADUAÇÃO EM ADMINISTRAÇÃO (PPGA) CURSO DE ESPECIALIZAÇÃO EM DESENVOLVIMENTO GERENCIAL

AVALIAÇÃO DE IMPACTO EM PROFUNDIDADE: CURSO DE DESENVOLVIMENTO GERENCIAL DE UMA IFES

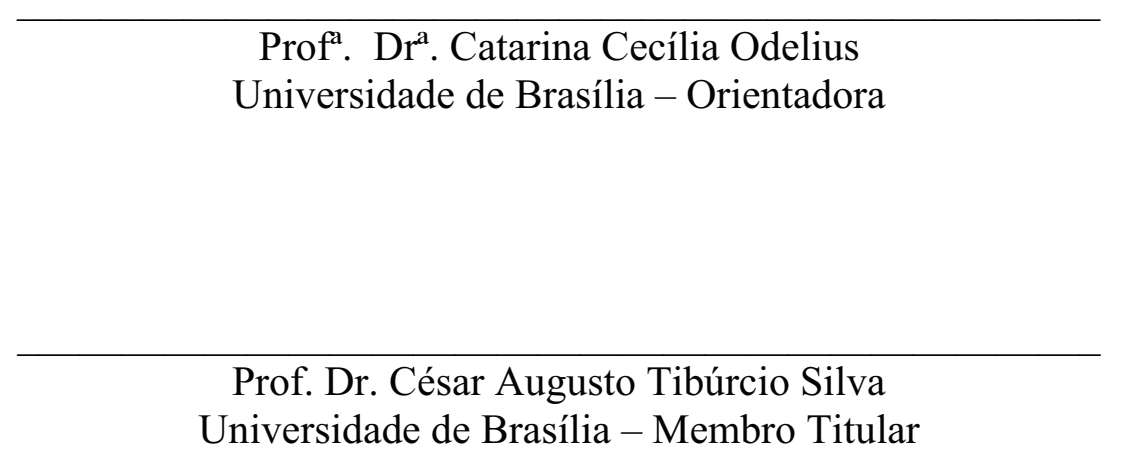

Universidade de Brasília - Membro Titular

Brasília, 15 de junho de 2007 
Feliz aquele que transfere o que sabe e aprende o que ensina.

(Cora Coralina) 


\section{AGRADECIMENTOS}

A Deus pela essência da vida, sem a qual não seria possível realizar esta pesquisa.

À Administração Superior da Universidade de Brasília, pelo pioneirismo na implantação e na implementação de políticas voltadas à valorização de seu corpo técnico-administrativo, em parceria com a Secretaria de Planejamento e suporte da Secretaria de Recursos Humanos, bem como a todos os gestores universitários, que contribuíram direta e indiretamente para a realização dessa parceria.

À Faculdade de Economia, Administração, Contabilidade e Ciência da Informação e Documentação (FACE), da Universidade de Brasília por acreditar que o investimento na implantação desse evento reflete inquestionavelmente em ação afirmativa de investimento do capital intelectual nessa modalidade de qualificação profissional.

À Nair Aguiar de Miranda pelo "sonho" da idealização materializada neste Curso.

À Professora Doutora Catarina Cecília Odelius, pela inestimável colaboração, disponibilidade, dedicação e orientação desta monografia, assim como pelos ensinamentos que possibilitaram nosso crescimento profissional.

Aos professores do Curso de Especialização em Desenvolvimento Gerencial que, com competência, seriedade e maestria souberam compartilhar seus conhecimentos.

Aos nossos colegas do Curso EDG pelo agradável convívio, amizade, ajuda em momentos difíceis na trajetória do curso, pela perseverança e compartilhamento do saber.

Aos alunos da $1^{\text {a }}$ turma do Curso EDG que prontamente se dispuseram a participar da pesquisa para elaboração desta monografia.

Aos nossos gerentes pelo apoio e desprendimento na liberação das nossas atribuições como servidores, para concluir este estudo. 
Aos colegas da Secretaria de Planejamento da Universidade de Brasília, cujo apoio facilitou a realização deste trabalho.

Aos meus pais Jardelino Silva Costa e Cândida Moraes Lima (in memoriam) que sempre confiaram em meus sonhos e me ensinaram a acreditar que é possível realizá-los, além de mostrarem que trabalho árduo, perseverança e honestidade são ferramentas ideais para se atingir metas e à minha sobrinha Alcione Sarah Santos Costa, que soube entender os momentos de ausência, oferecendo apoio e confiando no meu propósito.

Ao meu marido Valmir, às nossas filhas Gabriela e Cristina, que souberam entender os momentos de ausência e ofereceram carinho e amor incondicional nas horas mais difíceis.

A todos aqueles, não citados aqui nominalmente, que indistintamente contribuíram de uma forma ou de outra para a realização desta investigação. 


\section{RESUMO}

Esta pesquisa teve como objetivo avaliar o impacto em profundidade das ações de qualificação dos egressos da $1^{\text {a }}$ turma do Curso de Especialização em Desenvolvimento Gerencial promovido pela Universidade de Brasília. Inicialmente foi realizada uma revisão bibliográfica, com o referencial teórico abrangendo temas sobre organizações e suas principais abordagens, enfatizando-se o aspecto da aprendizagem organizacional, níveis de aprendizagem e transferência de aprendizagem. Posteriormente, tratou-se da importância da avaliação de treinamento e sua evolução histórica. A pesquisa foi feita junto aos 34 profissionais de nível superior de uma instituição educacional que participaram do curso. Para a coleta dos dados a respeito da freqüência de uso do conteúdo abordado em cada disciplina, o grau de importância do conteúdo abordado e a contribuição da disciplina para o trabalho realizado, foi elaborado instrumento específico, que também levantou dados pessoais e funcionais para caracterização dos pesquisados (tempo de trabalho, subordinados, atividades desenvolvidas na área meio, área fim e outros, além do tempo de trabalho na área e idade). Foi feita análise descritiva dos dados e os resultados apresentados indicam que os egressos do curso de Especialização em Desenvolvimento Gerencial percebem impacto positivo do curso, pois consideram que ocorreu transferência de aprendizagem da maioria dos conteúdos ministrados nas disciplinas, com aplicabilidade na sua unidade de trabalho. No entanto, sugere-se a realização de estudos mais aprofundados para esclarecer alguns dos resultados obtidos com este estudo.

Palavras-chave: treinamento, desenvolvimento, avaliação de treinamento, impacto em profundidade, suporte à transferência. 


\section{LISTA DE FIGURAS}

Figura 1 - Sistema de Treinamento

Figura 2 - Ciclo de Treinamento...................................................................................19

Figura 3 - Representação esquemática de uma sugestão de avaliação de necessidades de

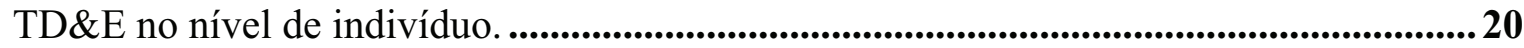

Figura 4 - Sistema de Treinamento e Desenvolvimento........................................................21

Figura 5 - Modelo de Avaliação Integrado e Somativo - MAIS ........................................ 24 


\section{LISTA DE TABELAS}

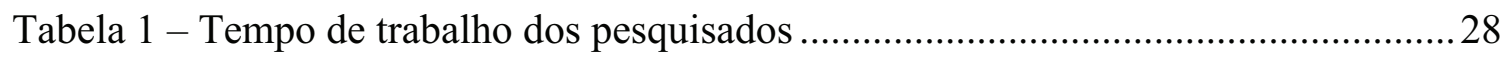

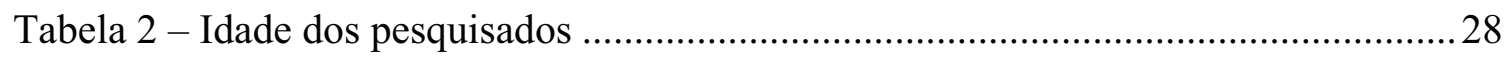

Tabela 3 - Quantitativo de subordinados dos pesquisados .........................................2 29

Tabela 4 - Distribuição das respostas de acordo com a freqüência de uso do conteúdo abordado em Introdução à Gestão do Ensino Superior ..................................................... 30

Tabela 5 - Distribuição das respostas de acordo com a freqüência de uso do conteúdo abordado em Gestão de Pessoas

Tabela 6 - Distribuição das respostas de acordo com a freqüência de uso do conteúdo abordado em Direito Aplicado ao Ensino Superior.

Tabela 7 - Distribuição das respostas de acordo com a freqüência de uso do conteúdo abordado em Contabilidade Pública

Tabela 8 - Distribuição das respostas de acordo com a freqüência de uso do conteúdo abordado em Planejamento, Administração e Gestão

Tabela 9 - Distribuição das respostas de acordo com a freqüência de uso do conteúdo abordado em Trabalho, Gestão e Subjetividade nas Organizações

Tabela 10 - Distribuição das respostas de acordo com a freqüência de uso do conteúdo abordado em Gestão Financeira Aplicada.....

Tabela 11 - Distribuição das respostas de acordo com a freqüência de uso do conteúdo abordado em Comportamento Organizacional

Tabela 12 - Distribuição das respostas de acordo com a freqüência de uso do conteúdo abordado em Direito Administrativo Aplicado....

Tabela 13 - Distribuição das respostas de acordo com a freqüência de uso do conteúdo abordado em Métodos e Técnicas de Pesquisa na Organização.

Tabela 14 - Grau de importância do conteúdo abordado, em todas as disciplinas, para a melhor compreensão da realidade cotidiana.

Tabela 15 - Média de importância das disciplinas para o uso cotidiano no trabalho e respectivo desvio-padrão

\section{LISTA DE QUADROS}

Quadro 1: Definições de treinamento 


\section{SUMÁRIO}

1 - Introdução

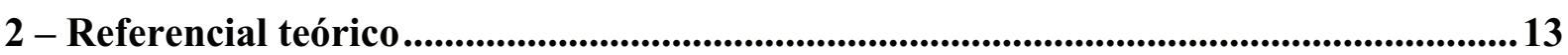

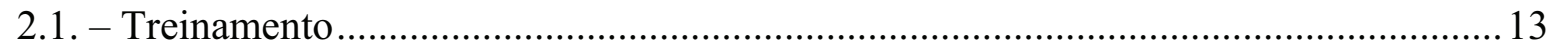

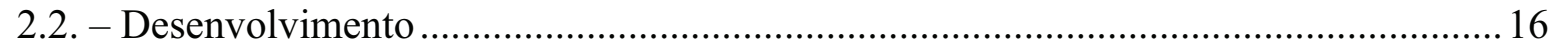

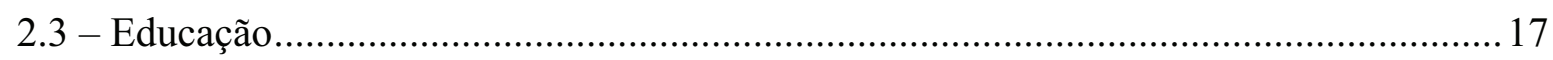

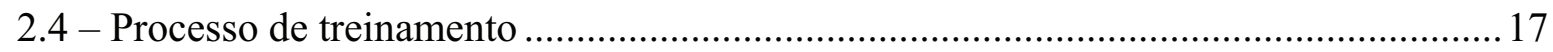

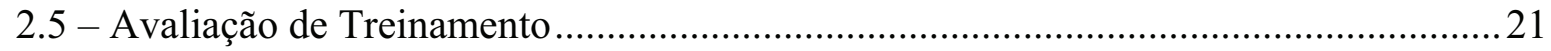

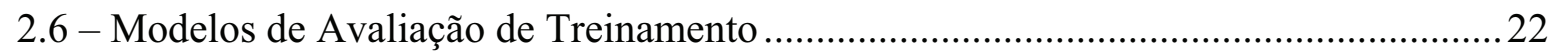

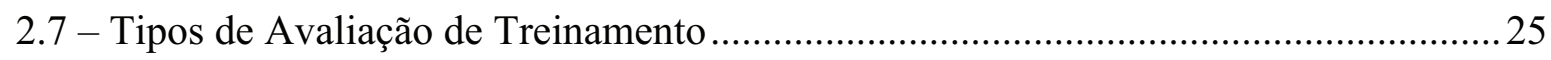

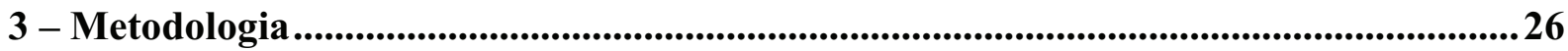

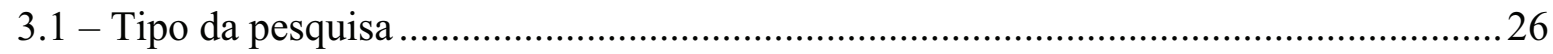

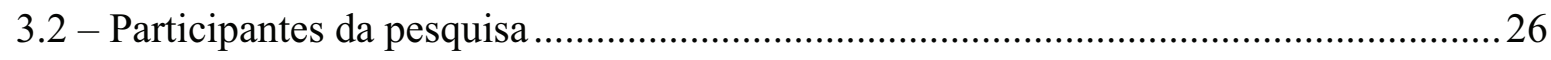

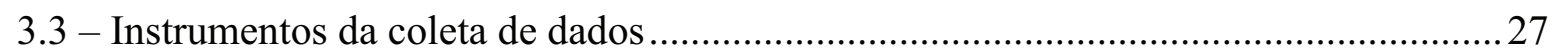

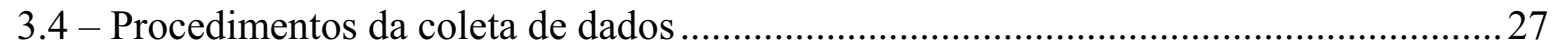

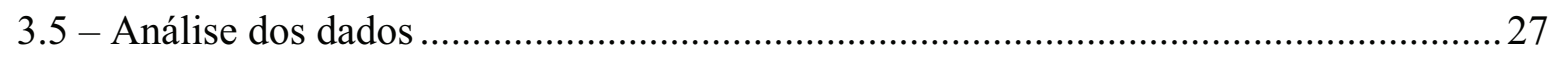

4 - Análise dos Dados e Resultados............................................................................28

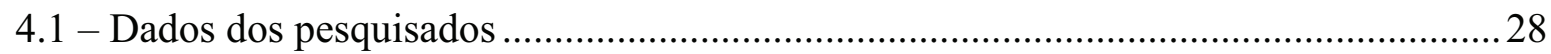

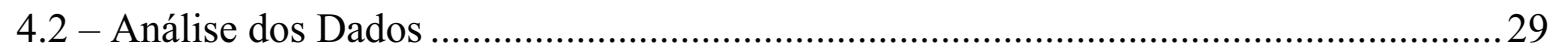

5 - Conclusão e Consideraçø̃es Finais ..........................................................................................50

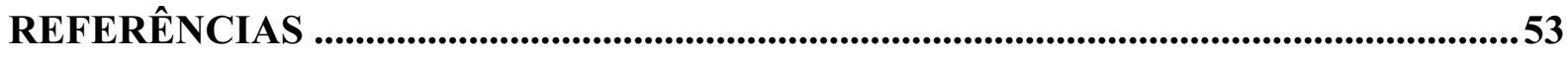

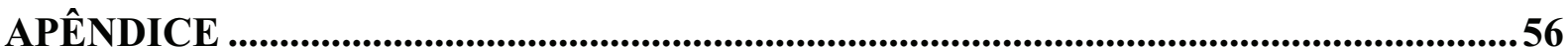




\section{1 - Introdução}

O ambiente organizacional vem passando por enormes transformações políticas e econômicas e, nesse contexto, faz-se necessário cada vez mais, conhecimentos, habilidades e atitudes que possam garantir com eficiência e eficácia os resultados diante das turbulências, incertezas e diversidades contemporâneas. A capacidade das instituições de formular e introduzir estratégias viáveis e flexíveis resulta do desenvolvimento de seus profissionais.

Segundo Freitas (2005), as características da conjuntura política, econômica e social tais como o avanço tecnológico, o aumento da expectativa de vida e a exigência dos consumidores fazem com que as empresas invistam cada vez mais na capacitação.

As mudanças do mundo moderno impactam, sem distinção, todo e qualquer tipo de organização, independentemente do porte e da natureza da atividade, seja ela pública ou privada, porém é importante lembrar que esses impactos ocorrem de forma diferenciada.

Para se manterem produtivas e eficazes, muitas técnicas e métodos de gestão vêm sendo criados, testados e aplicados para que as pessoas garantam às organizações resultados desejados. A capacitação tem sido um dos instrumentos aplicados com esse objetivo.

As novas relações do Estado que se apresentaram no Brasil a partir da década de 1990, passaram a demandar um perfil diferenciado do técnico governamental. Para atender aos desafios dessa nova fase, além da crescente impaciência da sociedade com as inadequações e ineficiências do aparelho estatal, o gerente público deverá estar convenientemente preparado em termos de capacitação profissional (TOHÁ; SOLARI, 1997).

No mundo atual as organizações se tornaram mais competitivas e necessitam possuir um quadro de colaboradores preparados, visto que não basta ter só o conhecimento, é preciso combinar processos que estimulem o conhecimento, aprimorem as habilidades e provoquem mudanças de atitudes. Identifica-se assim, uma tríade que representa a base da formação de qualquer profissional, conforme relatam Tohá e Solari (1997).

Na concepção de Freitas (2005), as organizações vencedoras serão aquelas que alcançarem reinventar sua forma de atrair, administrar, estimular, remunerar, capacitar, avaliar e premiar seus colaboradores.

Sensíveis às demandas constantes da sociedade moderna, as organizações vêm investindo principalmente na capacitação e qualificação com o intuito de proporcionar o desenvolvimento de seus empregados para atender a essas demandas. A aprendizagem nas organizações, no entendimento de Oliveira Jr. (2001), é um processo que origina novos conhecimentos na empresa e sobre o qual as organizações devem e podem tentar influenciar. 
Esse conhecimento é um recurso que assume papel de destaque e é um dos principais ativos estratégicos da organização.

Para Borges-Andrade (2006), as organizações precisam estar sempre atualizando sua força de trabalho através de conhecimentos e habilidades para serem viáveis e competitivas e para que possam deixar seus empregados, executivos e gestores capazes de demonstrar valores agregados às estratégias e aos negócios das organizações, acrescentando, ainda, que o trabalho vem ocupando um papel de destaque na vida das pessoas e que ganhou novas dimensões, ficando mais complexo. Diante das mudanças políticas e sociais existe atualmente uma demanda crescente por avaliação em treinamento, desenvolvimento e educação - TD\&E, tanto nas organizações que tradicionalmente fazem altos investimentos nessas atividades, quanto naquelas que visualizaram os valores estratégicos do conhecimento e do empenho na contínua qualificação de seus servidores, sendo que existem vários tipos de avaliação de treinamento, como será detalhado no referencial teórico (BORGES-ANDRADE, 2006).

A Universidade de Brasília, universidade federal que tem como objetivos promover o ensino, a pesquisa e a extensão com qualidade e formar cidadãos críticos, está preocupada com a melhoria de seus resultados e a capacitação dos profissionais que nela atuam. A gestão de pessoas voltada para a qualificação de seus servidores, atrelada ao Plano de Desenvolvimento Institucional (PDI), é questão relevante, inserida no planejamento maior da instituição, demanda esforços de professores, técnico-administrativos e alunos, e busca integrar as unidades e seus gestores ao processo de definição dos planos e prioridades institucionais, além de recursos orçamentários para pagamento dos docentes, materiais, bem como do custo de infra-estrutura. A expectativa do PDI, mencionado no Plano Anual de Atividades (PAA), no ano de 2005 (MIRANDA, 2005), é tornar cada vez mais evidentes os resultados da gestão universitária, mostrando à comunidade e à sociedade os acertos e limites enfrentados pelo gestor público, no exercício de suas funções. A Universidade de Brasília, nesses últimos anos, vem procurando aperfeiçoar, de forma contínua, seu quadro de funcionários para fazer face a essa demanda.

Nesse sentido, a Universidade de Brasília (UnB) vem investindo no desenvolvimento de conhecimentos, habilidades e atitudes de seus servidores, ou seja, o saber, o saber fazer e o ser/conviver, na expectativa de buscar maior aproximação para repensar as relações entre o trabalho, como ele é exercido e administrado e os processos de formação, incorporando, assim, técnicas de gestão para dotar de maiores eficácia e eficiência o funcionamento das instituições públicas, conforme proposta do Curso Especialização em Desenvolvimento Gerencial (EDG). A iniciativa da implantação do Curso (EDG) é um dos exemplos dessa 
política. Sob a responsabilidade da Faculdade de Economia, Administração, Contabilidade e Ciência da Informação e Documentação (FACE), e suporte da Secretaria de Recursos Humanos (SRH) da UnB, o curso teve seu início no segundo semestre de 2005.

De acordo com sua proposta de implantação, foi concebido com o objetivo de atender à demanda antiga da UnB na questão da especialização do seu corpo de administradores e gerentes, oferecendo-lhes o acesso ao conhecimento teórico acumulado, aperfeiçoando o processo de desenvolvimento de competências específicas, ampliando as habilidades técnicas de gestão e desenvolvendo atitudes positivas no que se refere ao trato dos fenômenos e processos administrativos e à promoção da renovação institucional.

Nesse entendimento, o Curso de Especialização em Desenvolvimento Gerencial (EDG) foi concebido como alternativa de se tratar questões estratégicas para suprir carências de pessoal qualificado no nível de gestão tática e operacional. Ressalta-se aqui o pioneirismo da Universidade de Brasília em promover essa modalidade de qualificação onde os indivíduos e suas competências se tornam elementos centrais de diferenciação estratégica na organização, conforme citado na proposta de concepção e implantação do EDG na Universidade de Brasília.

Observa-se, ainda, o empenho dos servidores-alunos em participar desse programa de qualificação, mesmo com a sobrecarga do horário de trabalho. Nesse aspecto existe a preocupação de verificar o impacto desse curso sobre o trabalho desenvolvido pelos participantes e averiguar em que aspectos o curso pode ser melhorado, na visão desses servidores. Para isso foram estudados modelos para a mensuração de resultados de treinamento, o que tem sido ponto de convergência de atenção das pesquisas na área de psicologia aplicada, segundo Pilati e Borges-Andrade (2004). Para esses autores, os modelos mais recentes para medir esses resultados compreendem o fenômeno de treinamento a partir de uma abordagem sistêmica, o que aprimorou o estudo de treinamento nas organizações, bem como ajudou nas investigações de questões que podem influenciar o resultado do treinamento no trabalho dos treinandos. Esses autores recomendam ainda que sejam feitas avaliações dos treinamentos em amplitude (influências mais gerais do treinamento sobre o indivíduo e seu desempenho) e em profundidade (influências específicas do treinamento sobre o indivíduo e seu desempenho), sendo que Abbad (2006), ressalta já existirem instrumentos validados para avaliação de impacto de treinamento em amplitude e que a avaliação em profundidade deve ser desenvolvida de modo customizado para cada treinamento.

No curso em estudo, a avaliação do treinamento em amplitude foi realizada recentemente (DANTAS, 2006), faltando realizar a avaliação em profundidade do curso. Em 
termos de delimitação, em virtude da complexidade desse tipo de avaliação, foram analisadas as disciplinas do curso, de acordo com o impacto percebido pelos participantes do curso, para serem avaliadas em profundidade e permitir nortear a realização desse tipo de avaliação. A pergunta deste estudo é qual o impacto sobre o desempenho e a avaliação em profundidade que os participantes do Curso de Especialização em Desenvolvimento Gerencial fazem a respeito das disciplinas abordadas no curso?

Nesse entendimento, o objetivo geral é analisar o impacto em profundidade das disciplinas do curso de Especialização em Desenvolvimento Gerencial sobre o desempenho dos servidores na Universidade de Brasília, descrever a importância das ações de Treinamento, Desenvolvimento e Educação (TD\&E) nas organizações, descrever a importância de avaliar impacto de treinamento em profundidade sob o foco de auto-avaliação, identificar como os servidores treinados percebem as disciplinas do curso EDG e o seu impacto sobre o desempenho de suas funções e verificar como os servidores treinados percebem seu desempenho após o curso de EDG.

Para atingir os objetivos propostos, esta monografia está estruturada em quinze seções, a saber: referencial teórico, treinamento, desenvolvimento, educação, processo de treinamento, avaliação de treinamento, medidas de avaliação de treinamento e tipos de avaliação de treinamento. Depois está apresentada a metodologia, a qual aborda os procedimentos e instrumento de pesquisa utilizados para coleta e análise dos dados, os resultados obtidos e as considerações finais. 


\section{2 - Referencial teórico}

\section{1 - Treinamento}

Segundo Vargas (1996 apud VARGAS; ABBAD, 2006), a origem de ações de expressão Treinamento e Desenvolvimento (T\&D) remonta aos primórdios das civilizações, quando o homem das cavernas transferia para suas gerações os conhecimentos básicos que garantissem a sobrevivência e a permanência da espécie humana.

Borges-Andrade e Abbad (1996) citam que uma das características primordiais do conceito de treinamento é a noção de que ele assume um esforço despendido pelas instituições para propiciar oportunidades de aprendizagem aos seus integrantes.

No Quadro 1 vislumbra-se a contribuição de pesquisadores sobre definições de treinamento:

\begin{tabular}{|l|l|}
\hline \multicolumn{1}{|c|}{ Autor } & \multicolumn{1}{|c|}{ DEFINIÇÕES DE TREINAMENTO } \\
\hline Hinrichs (1976) & $\begin{array}{l}\text { "Treinamento pode ser definido como quaisquer procedimentos, de iniciativa } \\
\text { organizacional, cujo objetivo é ampliar a aprendizagem entre os membros da } \\
\text { organização". }\end{array}$ \\
\hline Nadler (1984) & $\begin{array}{l}\text { "Treinamento é aprendizagem para propiciar melhoria de desempenho no } \\
\text { trabalho atual". }\end{array}$ \\
\hline Wexley (1984) & $\begin{array}{l}\text { "Treinamento é o esforço planejado pela organização para facilitar a } \\
\text { aprendizagem de comportamentos relacionados com o trabalho por parte de seus } \\
\text { empregados". }\end{array}$ \\
\hline $\begin{array}{l}\text { UK Department of } \\
\text { Employment (1971, apud } \\
\text { Latham 1988) }\end{array}$ & $\begin{array}{l}\text { "Treinamento é o desenvolvimento sistemático de padrões de comportamentos, } \\
\text { atitudes, conhecimento-habilidade, requeridos por um indivíduo, de forma a } \\
\text { desempenhar adequadamente uma dada tarefa ou trabalho". }\end{array}$ \\
\hline Goldstein (1991) & $\begin{array}{l}\text { "Treinamento é uma aquisição sistemática de atitudes, conceitos, conhecimento, } \\
\text { regras e habilidades que resultem na melhoria do desempenho no trabalho". }\end{array}$ \\
\hline
\end{tabular}

Quadro 1: Definições de treinamento

Fonte: Bastos (1991 apud VARGAS; ABBAD 2006, p. 140).

Já na concepção de Granjeiro (1999), há três etapas interdependentes, porém, perfeitamente distintas de educação profissional: formação profissional, que prepara o homem para exercer uma profissão; aperfeiçoamento ou desenvolvimento profissional, aquela que aperfeiçoa o homem para uma carreira dentro de uma profissão; e, treinamento, vista como a educação que prepara o homem para um cargo ou função. 
Granjeiro (1999, p. 8), enfatiza, também, que o "treinamento é processo educacional, aplicado de maneira sistemática e organizado, através do qual as pessoas aprendem conhecimentos, atitudes e habilidades em função de objetivos definidos".

Nesse cenário, o autor acrescenta, ainda, que o conteúdo do treinamento envolve quatro tipos de mudanças de comportamento:

a) transmissão de informações - compartilhar informações entre os treinados como um corpo de conhecimentos. O conteúdo é visto como ferramenta absolutamente necessária em grande número de programas de treinamento; b) desenvolvimento de habilidades, destrezas e conhecimentos relacionados de forma direta com desempenho do cargo atual ou futuro; c) desenvolvimento ou modificação de atitudes, entendido como mudanças de atitudes negativas para atitudes mais favoráveis, aumento da motivação, desenvolvimento da sensibilidade do pessoal de gerências e supervisão em relação a clientes e usuários; d) desenvolvimento de conceitos, possibilitando que o treinamento seja guiado de modo a elevar o nível de abstração e conceitualização de idéias e filosofias visando facilitar a aplicação de conceitos na prática administrativa e o nível de generalização, desenvolvendo gerentes para pensar de forma global e ampla.

Os principais objetivos do treinamento, na visão de Granjeiro (1999), são: preparar o pessoal para execução imediata de um trabalho, proporcionar oportunidades para o desenvolvimento contínuo e mudar atitudes das pessoas. Este autor afirma ainda que o treinamento, dessa forma, não é visto como despesa, mas investimento precioso cujo retorno é compensador para a organização.

Para Pantoja et al. (2005), o treinamento abrange três importantes dimensões. A primeira diz respeito à intencionalidade na melhoria do desempenho no trabalho, a segunda refere-se ao domínio desse processo por parte da organização e a última engloba sua natureza processual. Na visão desses autores, o treinamento como solução para problemas relativos a competência técnica vem sendo empregado para moldar os empregados aos seus novos papéis no âmbito da organização, tendo como funções essenciais a capacitação técnica das pessoas que englobam a empresa e a adaptação de comportamentos condizentes com os valores e os interesses organizacionais. E acrescentam que indivíduos comprometidos com os valores e filosofia da empresa inclinam-se a apresentar níveis mais altos de aplicação de novas aprendizagens no ambiente organizacional.

Para Abbad (1999), o treinamento propicia, cada vez mais, a intelectualização e especialização do funcionário, em todos os seus níveis. 
O treinamento está tradicionalmente ligado à identificação e ao efeito de superar as deficiências no desempenho dos empregados, aparelhamento dos empregados para novas atividades e adaptação de mão de obra a inserção de novas tecnologias no trabalho (BORGES-ANDRADE, 2002).

Treinamento é "qualquer atividade que procura deliberadamente, melhorar a habilidade de uma pessoa no desempenho do cargo" (HAMBLIN, 1978, p.20). Esse mesmo autor afirma que o objetivo imediato do treinamento é aprender, e aprender é uma situação que fazemos todo o tempo, quer nos peçam para fazê-lo, ou não.

No entendimento de Rocha (1999), os programas de treinamento visualizam inicialmente o empenho da organização em atingir seus objetivos e alcançam função dupla: no que diz respeito à instituição, perpetuam mecanismos conservadores e mantenedores do sistema e, em relação à pessoa, admitem auto-realização e evolução profissional, permitindo funcionar como mecanismo de mobilidade social e acesso ao emprego.

Na concepção de Sallorenzo (2000), treinamento relaciona-se ao processo sistemático de adquirir um conjunto de habilidades, atitudes, regras, conceitos, conhecimentos, normas que interagem com o trabalho.

Com o treinamento, o indivíduo potencializa suas capacidades, consegue se posicionar diante do mercado de trabalho de uma maneira mais amadurecida e aumenta sua habilidade para relacionar conhecimentos e analisar situações bem mais complexas (OLIVEIRA; ITUASSU, 2003).

Para Borges-Andrade (2002), na condição de técnica, o treinamento contempla princípios e prescrições, oferece alternativas para a resolução de problemas de trabalho no cargo; aplica referências teóricas da psicologia instrucional e cognitiva. Nesse contexto, acrescenta o autor, o treinamento procura identificar e vencer as deficiências no desempenho de empregados, conduzindo-os para novas funções e proporcionando retreinamento para a acomodação da mão-de-obra na inserção de novas tecnologias no trabalho.

São vários os aspectos que influenciam os resultados de um treinamento, sendo que quando se tem a motivação dos treinados e suporte organizacional para a aplicação de aprendizagem o desempenho do treinado fica favorecido. Um treinando satisfeito com o treinamento e com o desempenho do instrutor propenderia a perceber impacto positivo de conteúdos tratados no treinamento sobre seu desempenho no ambiente de trabalho e também estaria propenso a perceber os esforços praticados pela organização, no sentido de garantir suporte material à execução do aprendido. Também seria motivo de satisfação com o 
treinamento, na volta ao trabalho, o apoio e incentivo oferecido por chefes e colegas, tentando estabelecer oportunidades e facilitar a aplicação efetiva do aprendido (SALLORENZO, 2000).

Para Pilati e Borges-Andrade (2004), o treinamento leva a uma avaliação de maior resultado positivo na percepção de estímulo e desafio em todos os parâmetros relacionados à competência no trabalho. Para esses autores, Treinamento e Desenvolvimento (T\&D) é visto como contexto dependente e é entendido como um conjunto de cognições, afetos e ações direcionadas para criar condições necessárias, no ambiente de trabalho, para a execução de competências adquiridas.

Também para Vargas (1996 apud VARGAS; ABBAD 2006), o Treinamento e Desenvolvimento interagem como um só conceito e formam o conhecimento capaz de provocar, ao longo do tempo, uma mudança de ser e de pensar do indivíduo, através da interiorização de novos conceitos e no entender de novas habilidades.

\section{2 - Desenvolvimento}

Borges-Andrade (2002) relata que o conceito de desenvolvimento está relacionado a uma concepção mais abrangente, baseado na auto-gestão da aprendizagem, ou seja, nos conhecimentos que o indivíduo registra em toda a sua existência. Acrescenta, ainda, que o desenvolvimento está diretamente ligado à idéia de ações que ativam o livre crescimento individual, mesmo que essas ações não estejam diretamente relacionadas ao desempenho no próprio local de trabalho.

Segundo Nadler (1984 apud VARGAS; ABBAD 2006 p. 141/142), a expressão desenvolvimento de recursos humanos tem a função de referir à "promoção de aprendizagem para empregados (ou não), visando a ajudar a organização no alcance dos seus objetivos”, e acrescenta que desenvolvimento é a aprendizagem que engloba o crescimento individual, sem interferência com o trabalho específico. Esse autor defende o uso da expressão desenvolvimento de recursos humanos - porque nela estão introduzidos três interessantes conceitos: treinamento, desenvolvimento e educação; sendo que o "desenvolvimento engloba e não substitui o conceito de treinamento".

Desenvolvimento é um processo de aprendizagem porque favorece o amadurecimento de indivíduos de forma mais ampla, não especificamente para um posto de trabalho. (SALLORENZO, 2000). 
Na visão de Silva e Moraes (2004), um programa de desenvolvimento gerencial pode ser interpretado como treinamento de potencialização, e possibilita contribuir para o desenvolvimento das características pessoais dos treinandos. Acrescentam ainda, que o desenvolvimento de gerentes, tendo como intenção a transferência de informações, também abrange o desenvolvimento de conhecimentos, habilidades e atitudes, o que determina um conjunto de competências gerenciais. Uma vez que o corpo gerencial é primordial para a consecução dos objetivos organizacionais, sua ação pressupõe o conhecimento e compreensão de todo o mecanismo de desenvolvimento da instituição.

\section{3 - Educação}

O conceito de Educação definido na década de 50 e citado pelo Congresso Internacional de Ciências Administrativas, "refere-se a todos os processos pelos quais as pessoas adquirem compreensão do mundo, bem como capacidade para lidar com seus problemas" (VARGAS; ABBAD, 2006 p. 142).

No entendimento de Granjeiro (1999, p. 97) “a educação é preparo para a vida e pela vida" e a educação profissional é aqui entendida com a função de preparar o homem para exercer uma vida profissional. E, acrescenta, é preparar a pessoa para o ambiente dentro ou fora do seu trabalho.

A educação é ocupada principalmente com o desenvolvimento pessoal em oposição à relevância direta do cargo (HAMBLIN, 1978).

Para Sallorenzo (2000), educação é definida como eventos de aprendizagem que proporcionam capacitar indivíduos para agirem em postos de trabalhos específicos num futuro imediato, conceito semelhante ao de desenvolvimento para outros autores.

\section{4 - Processo de treinamento}

Na concepção de Abbad e Borges-Andrade (2004) a aprendizagem nas organizações ocorre no nível do indivíduo, podendo os seus efeitos proliferar pelos grupos e pelas organizações. Estas esperam que as ações de TD\&E produzam resultados sobre os indivíduos - aprendizagem, transferência e satisfação, e estimulem efeito nos processos de trabalho, aumentando a eficiência das equipes e a eficácia da organização. Esses autores entendem que, para a psicologia, a aprendizagem é vista como um processo individual de aquisição, retenção, generalização e transferência de conhecimento e esta última ocorre 
quando a mudança do indivíduo acontece em atividades não equivalentes às anteriores ou é verificada em situações diferentes daquelas em que ocorreu a aquisição do conhecimento.

Segundo Souza (2001), a abordagem da aprendizagem organizacional deriva do conceito de learning organization, ou organização da aprendizagem, que implica questões técnicas e aspectos sociais e comportamentais.

Borges-Andrade (1997) expõe um sistema de treinamento conforme ilustrado na Figura 1, representando um sistema de levantamento de necessidades de treinamento que contribui com o componente planejamento, que deverá orientar a execução do evento de treinamento. Esse sistema, na concepção do autor, fornecerá dados para a avaliação e retroalimentará os outros componentes do sistema, propondo possíveis ajustes em cada um deles.

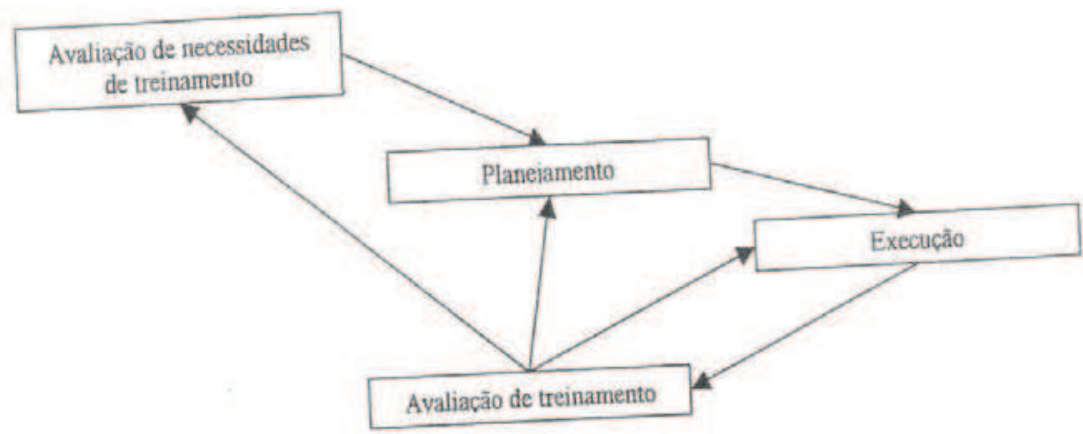

Figura 1: Sistema de Treinamento

Fonte: Borges-Andrade (1997, p.130).

$\mathrm{Na}$ concepção de Odelius (1999), o diagnóstico de necessidades deve ser um procedimento constante e não realizado somente uma vez por ano dentro das organizações.

No entendimento dessa autora, o ciclo de treinamento compreende quatro fases, conforme sintetizado na Figura 2. 


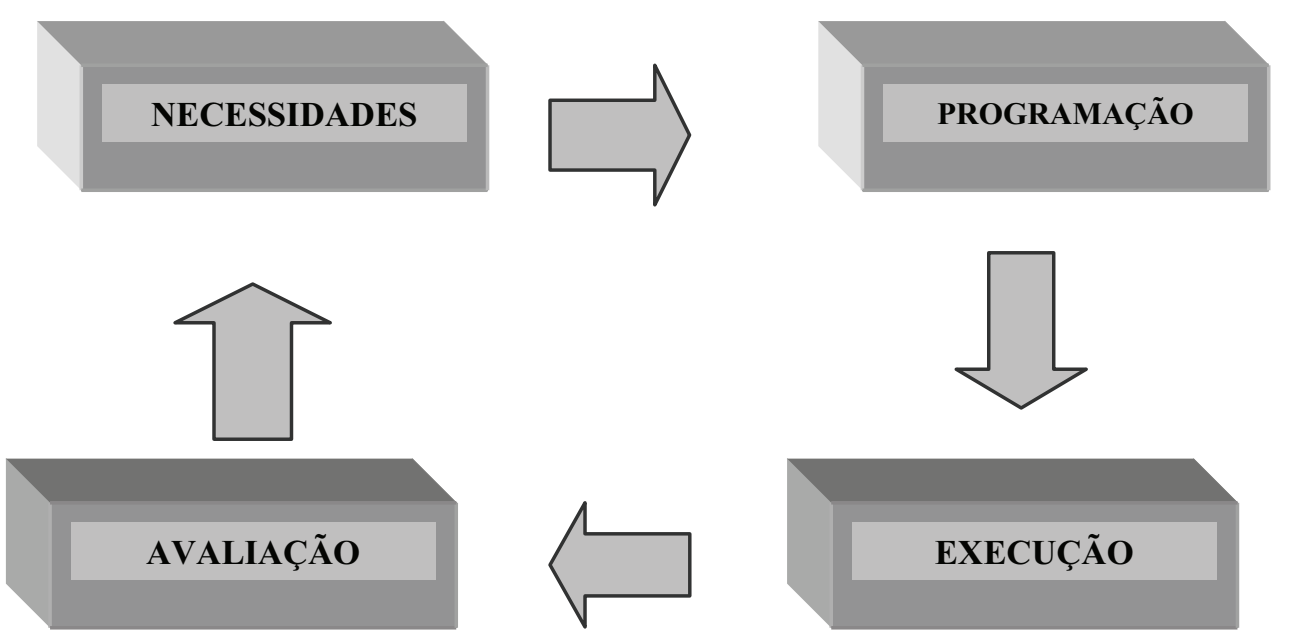

Figura 2: Ciclo de treinamento

Fonte: Odelius $(2005$, p.2).

Slide apresentado no Curso de Especialização em Desenvolvimento Gerencial.

Para Odelius, o levantamento de necessidades de treinamento deve-se buscar na: a) identificação e ocorrência de mudanças (no uso de tecnologias, na organização do trabalho, no trabalho e na organização); b) diferenças entre os requisitos do trabalho a ser realizado e a capacitação do trabalhador; c) problemas organizacionais (necessidade de diagnóstico mais aprofundado para identificar se é decorrente de falta de capacitação).

Para Odelius (1999), deve-se levar em consideração também os meios de levantamento de necessidade de treinamento que compreendem a) avaliação de desempenho; b) observação (trabalho ineficiente, quebra de equipamento, atrasos no trabalho, problemas disciplinares, alto nível de acidentes, entre outros; c) solicitação das chefias; d) pesquisa de levantamento de necessidades (entrevista e questionário); e) reuniões interdepartamentais; f) comparação dos requisitos dos cargos com as habilidades atuais do ocupante; g) modificação do trabalho; h) entrevista de saída; i) análise de cargos; j) relatórios, etc.

A necessidade e os objetivos dos treinamentos deverão ser definidos em função do diagnóstico realizado, que também fornecerá os dados para planejar e efetuar o treinamento.

Já para Abbad, Freitas e Pilati (2006, p. 247):

Para avaliar necessidades individuais de treinamento, desenvolvimento e educação, podem-se definir necessidades como (gaps) hiatos de competências, descritos em termos de conhecimentos, habilidades e atitudes (CHAs). Além disso, é preciso avaliar a magnitude do hiato, bem como quais são as conseqüências para a organização, se ignorá-lo. 


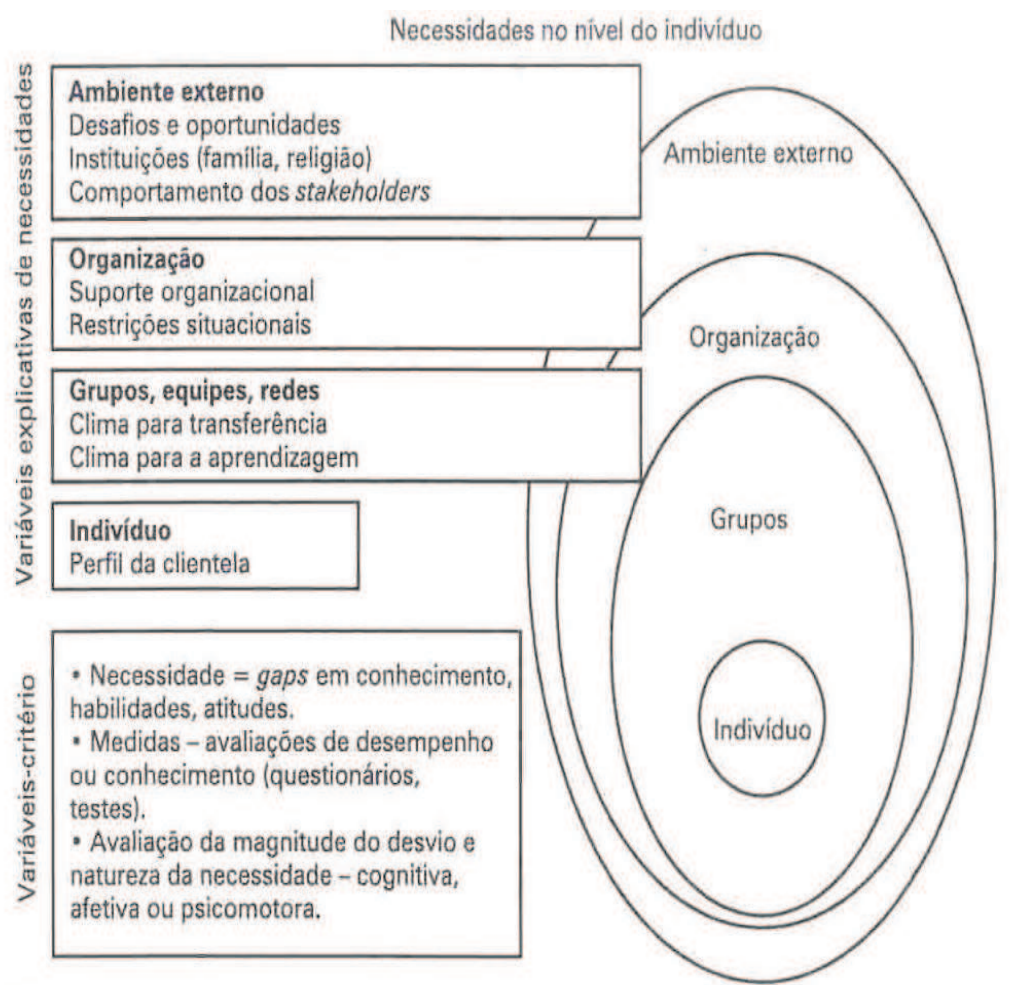

Figura 3: Representação esquemática de uma sugestão de avaliação de necessidades de TD\&E no nível de indivíduo.

Fonte: Abbad, Freitas e Pilati (2006, p.248).

Na concepção de Odelius (1999), o planejamento do treinamento deve ser considerado a partir do levantamento de necessidades e é preciso estabelecer a programação dos treinamentos, indicando objetivos, forma de desenvolvimento do programa, métodos e técnicas a serem utilizados, recursos necessários, população alvo, periodicidade, datas, etc.

O acompanhamento, na concepção de Souza (2001 p.15), "é a segunda fase do processo de gestão e ocorre durante a execução das atividades planejadas e destina-se a assegurar que a execução corresponda ao planejado". Ele permite detectar problemas e falhas na execução das tarefas e indicar correções de rumos alternativos para saná-los.

Para Souza (2001), a avaliação é uma conseqüência do acompanhamento e às vezes se confunde com ele, embora a experiência indique que nem sempre esses dois elementos andem juntos, mas eles formam o ciclo de controle de gestão. 


\section{5 - Avaliação de Treinamento}

Avaliar significa, literalmente, determinar, calcular, estimar, analisar. Avaliar um treinamento corresponde ao ato de julgar se compensou ou não, com base em algum critério de valor, o esforço de se fazer esse evento. (HAMBLIN, 1978).

Avaliação tem por fim precípuo comparar os resultados alcançados com o planejado.

Souza (2001) defende ainda que o processo de avaliação do treinamento necessita de padrões capazes de permitir uma contínua avaliação do processo em si e sistemático controle de seu funcionamento. Para ela devem ser utilizados padrões de quantidade, de qualidade, de tempo e de custo, que permitam avaliar e controlar pela comparação dos resultados e do desempenho.

No entendimento de Borges-Andrade (1997), adquire-se conhecimento claro da importância e influência do subsistema de avaliação de treinamento quando se observa a possibilidade de aperfeiçoamento constante de todo o sistema de treinamento, conforme sugere a Figura 4.

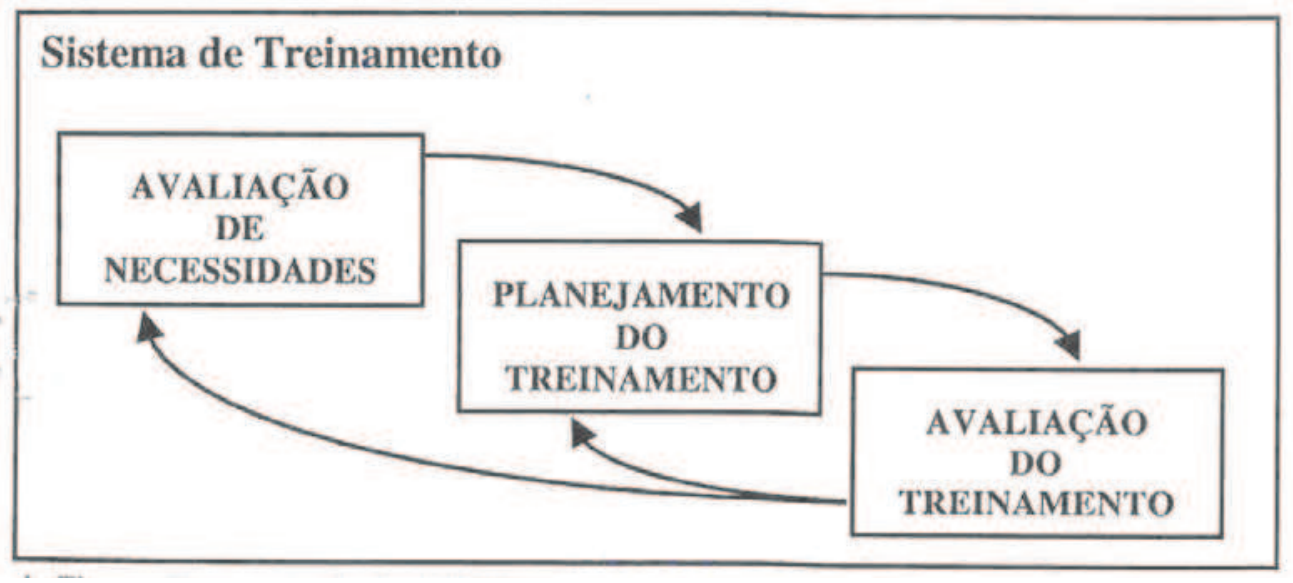

Figura 4: Sistema de Treinamento e Desenvolvimento.

Fonte: Borges-Andrade (1997 p.130).

Para Odelius (1999), a avaliação do treinamento pode oferecer diversos benefícios, entre os quais, encontram-se: o auxílio na adequação do treinamento com o plano estratégico da organização; o apoio no rastreamento daqueles que foram treinados e daqueles que necessitam de treinamento; a identificação das barreiras que confrontam as equipes e dificultam o progresso; o estabelecimento de critérios para reconhecimento e recompensa dos participantes e geração de oportunidades para uma retroalimentação que vise à melhoria contínua do programa.

No entendimento de Borges-Andrade e Abbad (1996), o papel da avaliação de treinamento seria o de coletar dados relativos aos efeitos nos diferentes níveis e compará-los 
com aqueles que seriam esperados. Nessa literatura os autores evidenciam, ainda, que o subsistema "avaliação de treinamento" seria o principal responsável pelo provimento de informações que garantem a retroalimentação e o aperfeiçoamento constante do sistema.

Na concepção de Hamblin (1978), o treinamento pode ser avaliado não só pelos seus objetivos financeiros, mas pelos termos dos seus objetivos intermediários, ou seja, pelo aperfeiçoamento das comunicações ou pelo aumento da felicidade das pessoas ou a diminuição da burocracia. A avaliação deve ser definida como um meio com o propósito de aperfeiçoar o treinamento e este, um meio para melhorar o desempenho geral (HAMBLIN, 1978).

Na concepção de Borges-Andrade (2002), a avaliação de treinamento vem a ser o principal responsável pelo provimento de informações e proporciona a retroalimentação e, conseqüentemente, o aperfeiçoamento constante do sistema. Acrescenta, que o seu papel é o de proceder à coleta de dados relativos aos efeitos nos diferentes níveis e confrontá-los com aqueles que seriam esperados.

Segundo Borges-Andrade (2006), quando a avaliação é executada, certamente esse processo propiciará ao profissional almejar plenamente a sua competência, e acrescenta:

A avaliação deve transcender sua característica de julgar o alcance dos objetivos ou verificar efetividade e ser também um meio de construir conhecimento a respeito da teoria e do sistema proposto ou em uso, ou predizer efetividade. O momento da avaliação deve se transformar, assim, em uma ocasião para realizar pesquisa aplicada (BORGES-ANDRADE, 2006, p. 345).

Odelius (2005, p.4), enfatiza que para se saber se o treinamento alcançou seus resultados é necessário:

Avaliar a reação dos treinandos, analisar os custos envolvidos, o retorno dos recursos investidos, o tempo necessário para alcançar a competência após a participação no treinamento, o uso do conteúdo do treinamento em situações de trabalho, a melhoria de desempenho, mudanças de atitudes, etc.

Freitas et al. (2006, p. 490) definem que:

Impacto de TD\&E no trabalho é medido em termos de transferência de TD\&E e da influência que os eventos instrucionais exercem sobre o desempenho subseqüente do participante desses eventos. Transferência de treinamento, nesse sentido, é a aplicação correta, no ambiente do trabalho, de conhecimentos, habilidades e atitudes (CHAs) adquiridos nesses eventos instrucionais.

2.6 - Modelos de Avaliação de Treinamento

A finalidade de modelo consiste em orientar o gestor, gerente ou treinador a resolver em quais atividades ele se encontra e a planejar o curso que deverá ser implantado (HAMBLIN, 1978). 
Para Hamblin (1978, p. 216), será desejável qualquer comportamento que:

a) for considerado desejável pelo treinando;

b) for aceito pelos superiores, iguais e subordinados do treinando como estando dentro dos limites da discrição do treinando e,

c) produzir resultados organizacionais.

Na concepção desse autor uma avaliação de treinamento deveria propor cinco níveis:

a) reação, que obtém atitudes e manifestação dos indivíduos treinados sobre os vários aspectos do treinamento;

b) aprendizagem, que avalia o treinamento adquirindo informações sobre a quantidade e o tipo de conhecimentos adquiridos pelos treinandos;

c) comportamento no cargo, que mede o desempenho das pessoas antes e depois do treinamento, ou se ocorreu a transferência de conhecimentos para o trabalho efetivamente realizado;

d) organização, verifica o funcionamento da aquisição ou mudanças dentro da organização em detrimento do treinamento; e

e) valor final, que vislumbra a todos os objetivos vinculados à organização, ou seja, se o treinamento correspondeu às expectativas ou não.

O Modelo Integrado de Avaliação do Impacto do Treinamento no Trabalho IMPACT, concebido por Abbad (1999), é composto por sete componentes: percepção de suporte organizacional, características do treinamento, características da clientela, reação, aprendizagem, suporte à transferência e impacto de treinamento no trabalho.

Para Pilati (2004 apud BORGES-ANDRADE, 2006), o modelo de avaliação de TD\&E é classificado em dois: a) genéricos, que definem conjuntos de variáveis com referência aos sistemas de TD\&E e podem influenciar a pesquisa e atuação profissional no campo, disponibilizando quadros de referência para entendimento dos fenômenos relacionados a esses processos, também contemplados no Modelo de Avaliação Integrado e Somativo - MAIS, proposto por Borges-Andrade, bem como os modelos de Kirkpatrick e de Hamblin; b) específicos, que são consolidados entre um conjunto de variáveis específicos e determinados resultados de TD\&E no nível individual, corroborando o modelo de Abbad (1999).

De acordo com Borges Andrade (2006), o Modelo de Avaliação Integrado e Somativo - MAIS, proposto por ele em 1982, está estruturado em cinco componentes, quais sejam: ambiente (necessidades, suporte, disseminação e efeitos em longo prazo), insumos, procedimentos, processos e resultados. Todos esses elementos visam formar variáveis que 
possam ser estruturadas e ofereçam referências que auxiliem na identificação de princípios a serem testados na organização.

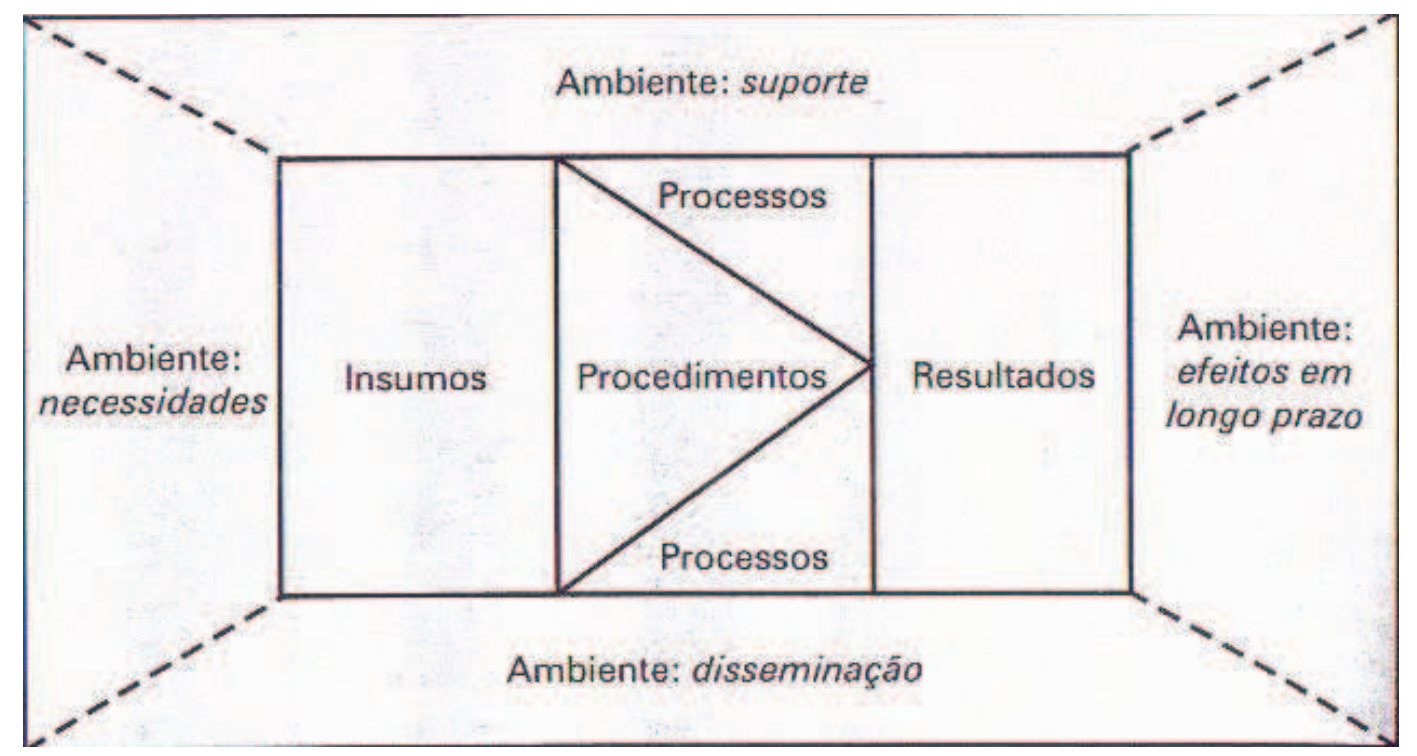

Figura 5: Modelo de Avaliação Integrado e Somativo - MAIS Fonte: Borges-Andrade (2006, p. 344).

Insumos, como componentes de avaliação, estão relacionados aos fatores físicos e sociais e compreendem as características dos treinados antes do processo do evento como, por exemplo, nível socioeconômico, de escolaridade, cargo ocupado, idade e outros.

Procedimentos referem-se à tecnologia instrucional utilizada e ao método de ensino que afeta diretamente os resultados de aprendizagem como tipo de direcionamento de aprendizagem, adequação instrucional dos materiais de TD\&E, uso de exercícios práticos, clareza e precisão dos objetivos etc.

Processos se relacionam com o desenvolvimento do comportamento do treinado, por ocasião em que os procedimentos são implementados, como por exemplo, tempo dedicado à instrução, compartilhamento de experiências, registros de atrasos e ausências durante o treinamento etc.

O componente resultado diz respeito aos efeitos imediatos alcançados no treinamento. E, finalmente, o componente ambiente, que engloba necessidade, suporte, disseminação e efeitos em longo prazo e baseia-se em todas as condições, atividades e eventos onde o treinamento é aplicado. Exemplos: instalação de treinamento, acesso, expectativa organizacional de suporte, gestão de desempenho na organização, natureza da divulgação do 
evento, canais eletrônicos, visuais e auditivos, e os efeitos advindos do treinamento no que respeita a mudanças, clima e cultura organizacional entre outros.

\section{7 - Tipos de Avaliação de Treinamento}

A mudança provocada no nível de comportamento no cargo poderia ser observada pelo impacto do treinamento no trabalho. Segundo Hamblin (1978), esse construto seria formado por duas facetas, a primeira, denominada de impacto em amplitude, que corresponderia ao efeito provocado pelo treinamento em todas as competências exigidas para a execução das tarefas no cargo de forma mais abrangente e, a segunda, de impacto em

profundidade, que seria relativo, estritamente, à aplicação daquelas competências adquiridas em treinamento. A avaliação em amplitude é também conhecida como avaliação em largura.

Para Sallorenzo (2000), o impacto do treinamento pode ser medido de três formas: - auto-avaliação em amplitude ou largura (também denominado impacto de treinamento no desempenho), que busca avaliar se o desempenho teve impacto, também, em atividades não relacionadas com o que foi ensinado no treinamento. Se caracteriza pela especificação de efeitos do TD\&E em dimensões mais gerais de comportamento;

- auto-avaliação em profundidade (também conhecido como sinônimo de transferência de treinamento), que avalia o impacto das atividades estritamente relacionadas aos conteúdos administrados nos treinamentos, em que os itens são prescritos a partir dos objetivos específicos dos eventos. Os instrumentos de coleta de dados medem o uso dos conhecimentos e habilidades aprendidos ou atitudes desenvolvidas;

- hetero-avaliação em que os supervisores ou colegas dos treinados avaliam o impacto do treinamento sobre o desempenho destes. 


\section{3 - Metodologia}

Por metodologia vários autores entendem ser o caminho melhor para atingir objetivos préestabelecidos. É um estudo metódico e crítico que possibilita "explorar formas alternativas de análise de dados e/ou refinar análises já realizadas com o mesmo banco de informações" (SALLORENZO, 2000 p. 38).

Na concepção de Costa (2001), o método é um conjunto de regras para alcançar os objetivos pré-estabelecidos. Os filósofos Descartes, Hegel e Spinoza estudaram cuidadosamente os métodos porque estavam compromissados em descobrir a maneira racional para atingir a verdade (POLITZER, 1991).

O método é visto como um instrumental indispensável para atingir determinado objetivo, no que respeita ao estudo e à pesquisa, em qualquer área do conhecimento.

\section{1 - Tipo da pesquisa}

Foi realizada pesquisa quantitativa, qualitativa, descritiva e semi-estruturada, pois, dessa forma, são detectados os dados básicos para o desenvolvimento e compreensão das relações entre os atores sociais e sua situação (VERGARA, 2000). Segundo essa autora, a pesquisa é descritiva quando busca identificar quais situações, atitudes ou opiniões estão manifestos em uma determinada população.

Na concepção de Gaskell (2002), é tecnicamente conveniente o emprego simultâneo de métodos qualitativos e quantitativos de análise, visto que alguns aspectos avaliados demandam o uso de múltiplos métodos e fontes de avaliação.

Quanto aos meios, a pesquisa caracterizou-se como bibliográfica, documental e de campo (VERGARA, 2000), em que foram colhidos os dados diretamente com os participantes, onde ocorre o fenômeno investigado.

\section{2 - Participantes da pesquisa}

A pesquisa foi realizada junto aos servidores que concluíram o Curso de Especialização em Desenvolvimento Gerencial da Universidade de Brasília, na primeira turma, num total de 34 gestores. 
3.3 - Instrumentos da coleta de dados

A análise documental abrangeu a proposta do Curso de Desenvolvimento Gerencial, que foi realizado no período de 1\%/8/2005 a 31/7/2006 que foi enviada para aprovação do Decanato de Pesquisa e Pós-Graduação, bem como planos de ensino e ementas das disciplinas distribuídos aos alunos.

Um questionário foi desenvolvido a partir da análise documental para avaliar a percepção dos participantes quanto ao impacto das diversas disciplinas em seu dia-a-dia. Foram levantados três aspectos abordando freqüência de uso, importância para a atuação cotidiana, bem como analisar de que forma o conteúdo de cada uma das disciplinas tem contribuído para o seu trabalho (ver Apêndice A). O instrumento de coleta de dados foi aplicado no período de 15 a 31 de maio de 2007.

\section{4 - Procedimentos da coleta de dados}

A coleta de dados a partir do questionário foi agendada previamente, realizada e registrada pelos dois membros da pesquisa, no local de trabalho dos participantes que compõem a população desta pesquisa. O questionário foi distribuído para preenchimento e recolhido em seguida. Também foi garantido aos participantes, sigilo total e absoluto sobre as informações coletadas, bem como a omissão de nomes no resultado da pesquisa.

\section{5 - Procedimentos de análise dos dados}

Os documentos foram submetidos à análise de conteúdo segundo (FRANCO, 2003) e os dados coletados com o questionário foram tabulados, sendo efetuada estatística descritiva (distribuição de freqüência, média e desvio-padrão). Um questionário foi excluído da pesquisa, pois não apresentava variabilidade nas respostas.

Foram usadas as fórmulas abaixo para cálculo o da média e desvio padrão:

Média $(\mathrm{x}) \mathrm{x}=\sum \mathrm{xi} / \mathrm{n}$

Variância (S2) $\mathrm{S} 2=\sum(\mathrm{xi}-\mathrm{x}) 2 /(\mathrm{n}-1)$

Desvio Padrão (S) $\mathrm{S}=\sqrt{ } 2 \sum(\mathrm{xi}-\mathrm{x}) 2 /(\mathrm{n}-1)$

Desvio padrão para uma população: (S) $S=\sqrt{ } 2 \sum(x i-x) 2 /(n)$ 


\section{4 - Análise dos Dados e Resultados}

4.1 - Dados dos pesquisados

Em relação ao grupo de pesquisados, nove trabalham em atividade de apoio em unidade acadêmica, dezesseis em unidade administrativa, três pessoas na área de suporte à administração superior, três em áreas técnicas e três envolvendo tanto a área acadêmica quanto a área administrativa da Instituição. Vinte pessoas são do sexo feminino e quatorze do masculino.

O tempo de trabalho na Instituição variou de 3 a 38 anos, conforme especificado abaixo, na Tabela 1, sendo que dois pesquisados não responderam:

Tabela 1 - Tempo de trabalho dos pesquisados

\begin{tabular}{c|c|c|c|c}
\hline Tempo & Freqüência & $\%$ & $\%$ válido & $\%$ acumulado \\
\hline 3 & 1 & 3,03 & 3,13 & 3,13 \\
9 & 1 & 3,03 & 3,13 & 6,25 \\
12 & 2 & 6,06 & 6,25 & 12,50 \\
13 & 2 & 6,06 & 6,25 & 18,75 \\
18 & 1 & 3,03 & 3,13 & 21,88 \\
20 & 5 & 15,15 & 15,63 & 37,50 \\
22 & 3 & 9,09 & 9,38 & 46,88 \\
24 & 1 & 3,03 & 3,13 & 50,00 \\
26 & 5 & 15,15 & 15,63 & 65,63 \\
27 & 3 & 9,09 & 9,38 & 75,00 \\
28 & 5 & 15,15 & 15,63 & 90,63 \\
29 & 1 & 3,03 & 3,13 & 93,75 \\
31 & 1 & 3,03 & 3,13 & 96,88 \\
38 & 1 & 3,03 & 3,13 & 100,00 \\
\hline Total & 32 & 96,97 & 100,00 & \\
Sem resposta & 2 & 3,03 & & \\
Total & 34 & 100 & & \\
\hline
\end{tabular}

Fonte: Dados da pesquisa

Quanto à idade dos pesquisados, dois não responderam e as demais estão discriminadas na Tabela 2, onde podemos observar que há um maior número de pesquisados na faixa de 46 a 55 anos. A faixa de idade dos pesquisados variou de 32 a 61 anos, sendo a idade média igual a 47,34 anos e desvio padrão de 6,64.

Tabela 2 - Idade dos pesquisados

\begin{tabular}{l|l|l|l|l|l|l}
\hline 30 a 35 anos & 36 a 40 anos & 41 a 45 anos & 46 a 50 anos & 51 a 55 anos & 56 a 60 anos & 61 a 65 anos \\
\hline 2 pessoas & 1 pessoa & 7 pessoas & 11 pessoas & 9 pessoas & 1 pessoa & 1 pessoa \\
\hline
\end{tabular}

Os dados sobre a quantidade de subordinados, de acordo com os pesquisados, estão apresentados na Tabela 3 . 
Tabela 3 - Quantitativo de subordinados dos pesquisados

\begin{tabular}{c|c|c|c|c}
\hline Subordinados & Freqüência & $\%$ & $\%$ válido & $\%$ acumulado \\
\hline 0 & 7 & 21,21 & 21,88 & 21,88 \\
1 & 2 & 6,06 & 6,25 & 28,13 \\
2 & 1 & 3,03 & 3,13 & 31,25 \\
3 & 2 & 6,06 & 6,25 & 37,50 \\
4 & 3 & 9,09 & 9,38 & 46,88 \\
5 & 1 & 3,03 & 3,13 & 50,00 \\
6 & 1 & 3,03 & 3,13 & 53,13 \\
7 & 1 & 3,03 & 3,13 & 56,25 \\
8 & 3 & 9,09 & 9,38 & 65,63 \\
10 & 1 & 3,03 & 3,13 & 68,75 \\
12 & 1 & 3,03 & 3,13 & 71,88 \\
13 & 2 & 6,06 & 6,25 & 78,13 \\
14 & 1 & 3,03 & 3,13 & 81,25 \\
20 & 2 & 6,06 & 6,25 & 87,50 \\
25 & 1 & 3,03 & 3,13 & 90,63 \\
52 & 1 & 3,03 & 3,13 & 93,75 \\
150 & 1 & 3,03 & 3,13 & 96,88 \\
181 & 1 & 3,03 & 3,13 & 100,00 \\
\hline Total & 32 & 96,97 & 100,00 & \\
Sem resposta & 2 & 3,03 & & \\
Total & 34 & 100 & & \\
\hline Fonte: Dad & 34 & \multicolumn{3}{|l}{} \\
\hline
\end{tabular}

Fonte: Dados da pesquisa

Pelos dados apresentados, sete pesquisados não têm subordinados, quinze têm de 1 a 10, seis têm entre 12 a 20 subordinados, e quatro pesquisados com 25, 52, 150 e 181 subordinados, respectivamente.

\section{2 - Análise dos Dados}

O conteúdo previsto para ser abordado na disciplina "Introdução à Gestão do Ensino Superior" e a freqüência com que os pesquisados utilizam esse conteúdo estão apresentados na Tabela 4.

Pelos dados apresentados, "Conceitos e objetivos do serviço público" é um conteúdo sempre usado por $45,5 \%$ dos pesquisados. Esse conteúdo e "Conceitos e objetivos do ensino superior público" foram os mais apontados pelos pesquisados, com mais de três quartos dos pesquisados afirmando que os usam sempre ou quase sempre.

Os conteúdos menos usados ${ }^{1}$, de acordo com os pesquisados, foram: “Características das IES e das universidades brasileiras" (51,5\%), "Políticas de funcionamento das IES (desafios e perspectivas)" (45,5\%) e "Evolução do sistema de ensino superior" (39,55\%). É curioso notar que o tópico que aborda as características das IES foi apontado como o menos usado pelos pesquisados, que também afirmaram usar mais um conteúdo que se refere ao

\footnotetext{
${ }^{1}$ A classificação "menos usados" abrange as respostas: nunca usa, quase nunca e às vezes, enquanto "mais usados" inclui quase sempre e sempre.
} 
passado (item 3) do que o que se refere à política de funcionamento das IES, que aborda desafios e perspectivas. Seria interessante um aprofundamento de pesquisa para tentar descobrir por que isso ocorre.

Tabela 4 - Distribuição das respostas de acordo com a freqüência de uso do conteúdo abordado em Introdução à Gestão do Ensino Superior

\begin{tabular}{|c|c|c|c|c|c|c|c|c|}
\hline & Conteúdo & Nunca & $\begin{array}{l}\text { Quase } \\
\text { nunca }\end{array}$ & $\begin{array}{c}\text { Às } \\
\text { vezes }\end{array}$ & $\begin{array}{l}\text { Quase } \\
\text { sempre }\end{array}$ & Sempre & Média & $\begin{array}{l}\text { Desvio } \\
\text { padrão }\end{array}$ \\
\hline 1 & $\begin{array}{l}\text { Conceitos e objetivos do serviço } \\
\text { público }\end{array}$ & 0 & 6,1 & 18,2 & 30,3 & 45,5 & 3,15 & 0,93 \\
\hline 2 & $\begin{array}{l}\text { Conceitos e objetivos do ensino } \\
\text { superior público }\end{array}$ & 3,0 & 6,1 & 12,1 & 36,4 & 42,4 & 3,09 & 1,03 \\
\hline 3 & $\begin{array}{l}\text { Evolução do sistema de ensino superior } \\
\text { Características das IES e das }\end{array}$ & 6,1 & 15,2 & 18,2 & 30,3 & 30,3 & 2,64 & 1,23 \\
\hline 4 & $\begin{array}{l}\text { universidades brasileiras (criação, } \\
\text { concepção, missão, objetivos, política, } \\
\text { finalidades) }\end{array}$ & 6,1 & 12,1 & 33,3 & 18,2 & 30,3 & 2,55 & 1,21 \\
\hline 5 & $\begin{array}{l}\text { Políticas de funcionamento das IES } \\
\text { (desafios e perspectivas) }\end{array}$ & 6,1 & 6,1 & 33,3 & 15,2 & 39,4 & 2,76 & 1,21 \\
\hline 6 & $\begin{array}{l}\text { IES na atualidade (relevância, } \\
\text { qualidade e internacionalizacão) }\end{array}$ & 6,1 & 6,1 & 18,2 & 27,3 & 39,4 & 2,97 & 1,22 \\
\hline
\end{tabular}

Fonte: Dados da pesquisa

A maior média obtida nesta disciplina foi para o conteúdo "Conceitos e objetivos do serviço público" com 3,15 e com o menor desvio padrão 0,93 .

"Características das IES e das universidades brasileiras (criação, concepção, missão, objetivos, política, finalidades)" e "Políticas de funcionamento das IES (desafios e perspectivas)" alcançaram médias 2,55 e 2,76, respectivamente, com o mesmo desvio padrão, de 1,21 .

O conteúdo previsto para ser abordado na disciplina "Gestão de Pessoas" e a freqüência com que os pesquisados utilizam esse conteúdo estão apresentados na Tabela 5.

Com base nas respostas dadas pelos pesquisados, verificou-se que apenas para a disciplina "Gestão de Pessoas" houve 3\% de respostas afirmando que os conteúdos "Características que influenciam relações sindicais e trabalhistas" e "Conceitos de recrutamento, seleção e suas características" não tinham sido abordados. Devido ao pequeno índice, é provável que esse percentual se deva a um participante do curso que tenha faltado a essas aulas e não tenha lido os textos disponibilizados na disciplina. Em função disso, esses dados serão desconsiderados para o cálculo de percentuais de uso do conteúdo.

Pela tabela apresentada, observa-se que os conteúdos mais usados pelos pesquisados foram "Conceitos de gestão de pessoas, teorias e abordagens" (81,8\%), "Aspectos que influenciam os resultados organizacionais" (78,7\%) e "Gestão do conhecimento e desenvolvimento humano" (72,7\%). 
Tabela 5 - Distribuição das respostas de acordo com a freqüência de uso do conteúdo abordado em Gestão de Pessoas

\begin{tabular}{|c|c|c|c|c|c|c|c|c|c|}
\hline & Conteúdo & Nunca & $\begin{array}{l}\text { Quase } \\
\text { nunca }\end{array}$ & $\begin{array}{c}\text { As } \\
\text { vezes }\end{array}$ & $\begin{array}{l}\text { Quase } \\
\text { sempre }\end{array}$ & Sempre & $\begin{array}{l}\text { Nãofoi } \\
\text { abordado }\end{array}$ & Média & $\begin{array}{l}\text { Desvio } \\
\text { padrão }\end{array}$ \\
\hline 1 & $\begin{array}{l}\text { Conceitos de gestão de } \\
\text { pessoas, teorias e } \\
\text { abordagens }\end{array}$ & 0 & 3,0 & 15,2 & 39,4 & 42,4 & 0 & 3,21 & 0,81 \\
\hline 2 & $\begin{array}{l}\text { Aspectos que influenciam } \\
\text { os resultados } \\
\text { organizacionais }\end{array}$ & 3,0 & 3,0 & 15,2 & 24,2 & 54,5 & 0 & 3,24 & 1,02 \\
\hline 3 & $\begin{array}{l}\text { Características que } \\
\text { influenciam relações } \\
\text { sindicais e trabalhistas }\end{array}$ & 6,3 & 9,4 & 43,8 & 12,5 & 28,1 & 3,0 & 2,63 & 1,17 \\
\hline 4 & $\begin{array}{l}\text { Características e análise de } \\
\text { descrição de cargos, } \\
\text { ergonomia e } \\
\text { competências. } \\
\text { Conceitos de }\end{array}$ & 3 & 12,1 & 18,2 & 27,3 & 36,4 & 0 & 2,84 & 1,15 \\
\hline 5 & $\begin{array}{l}\text { recrutamento, seleção e } \\
\text { suas características }\end{array}$ & 9,4 & 18,8 & 25,0 & 12,5 & 34,4 & 3,0 & 2,69 & 1,37 \\
\hline 6 & $\begin{array}{l}\text { Processo de gestão de } \\
\text { desempenho. }\end{array}$ & 3,0 & 3,0 & 24,2 & 21,2 & 48,5 & 0 & 3,09 & 1,05 \\
\hline 7 & $\begin{array}{l}\text { Gestão do conhecimento e } \\
\text { desenvolvimento humano }\end{array}$ & 0 & 9,1 & 18,2 & 18,2 & 54,5 & 0 & 3,18 & 1,03 \\
\hline 8 & Conceitos de TD\&E & 3,0 & 12,1 & 27,3 & 30,3 & 18,2 & 0 & 2,69 & 1,18 \\
\hline 9 & $\begin{array}{l}\text { Características de } \\
\text { remuneração e } \\
\text { produtividade }\end{array}$ & 9,1 & 21,2 & 33,3 & 12,1 & 24,2 & 0 & 2,21 & 1,27 \\
\hline 10 & $\begin{array}{l}\text { Segurança, medicina do } \\
\text { trabalho e saúde } \\
\text { ocupacional. }\end{array}$ & 9,1 & 24,2 & 24,2 & 6,1 & 33,3 & 0 & 2,31 & 1,40 \\
\hline 11 & $\begin{array}{l}\text { Caracteristicas das } \\
\text { instituições e sua } \\
\text { responsabilidade social }\end{array}$ & 0 & 9,1 & 24,2 & 21,2 & 45,5 & 0 & 3,03 & 1,03 \\
\hline
\end{tabular}

Fonte: Dados da pesquisa

Os conteúdos menos utilizados, de acordo com os pesquisados, foram "Características de remuneração e produtividade" (63,6\%), "Características que influenciam relações sindicais e trabalhistas" $(59,5 \%)$.

Apesar de dois terços dos pesquisados $(66,7 \%)$ afirmarem fazer uso do conceito "Características das instituições e sua responsabilidade social", verifica-se que (33,3\%) não fazem uso dessa matéria. Seria útil analisar por que ocorre tal fato.

De acordo com a pesquisa, o item "Segurança, medicina do trabalho e saúde ocupacional" foi pouco usado por $57,5 \%$ dos pesquisados. É pertinente também a realização de futuros estudos para descobrir qual a causa de tal situação.

Conforme os dados apresentados, o conteúdo "Conceitos de recrutamento, seleção e suas características" quase nunca é usado por 53,2\% dos pesquisados. Seria interessante pesquisar as razões que levam profissionais que são responsáveis pela gestão de desempenho 
de uma equipe a não utilizarem esses conhecimentos. "Processo de gestão de desempenho" é sempre usado por $48,5 \%$ dos pesquisados. O conceito "Aspectos que influenciam os resultados organizacionais" alcançou a maior média, com 3,24 e desvio- padrão 1,02, enquanto que o menor desvio padrão ficou com o conteúdo "Conceitos de gestão de pessoas, teorias e abordagens", atingindo 0,81, com média 3,21

O conteúdo que obteve ao maior desvio padrão, foi "Segurança, medicina do trabalho e saúde ocupacional", com 1,40 e média 2,31, o que indica uma maior variabilidade das respostas.

O conteúdo previsto para ser abordado na disciplina "Direito Aplicado ao Ensino Superior" e a freqüência com que os pesquisados utilizam esse conteúdo estão apresentados na Tabela 6.

Tabela 6 - Distribuição das respostas de acordo com a freqüência de uso do conteúdo abordado em Direito Aplicado ao Ensino Superior

\begin{tabular}{|c|c|c|c|c|c|c|c|c|}
\hline & Conteúdo & Nunca & $\begin{array}{l}\text { Quase } \\
\text { nunca }\end{array}$ & Às vezes & $\begin{array}{l}\text { Quase } \\
\text { sempre }\end{array}$ & Sempre & Média & $\begin{array}{l}\text { Desvio } \\
\text { padrão }\end{array}$ \\
\hline 1 & $\begin{array}{l}\text { Constituição jurídica das } \\
\text { universidades }\end{array}$ & 9,1 & 18,2 & 33,3 & 9,1 & 30,3 & 2,33 & 1,32 \\
\hline 2 & $\begin{array}{l}\text { Normas e legislação vigentes } \\
\text { nas IFES }\end{array}$ & 3,0 & 6,1 & 21,2 & 27,3 & 42,4 & 3,00 & 1,07 \\
\hline 3 & Constituição de 1998 & 3,0 & 18,2 & 12,1 & 27,3 & 36,4 & 2,85 & 1,26 \\
\hline 4 & Lei de Diretrizes e Bases & 6,1 & 15,2 & 21,2 & 18,2 & 39,4 & 2,70 & 1,29 \\
\hline 5 & $\begin{array}{l}\text { Responsabilidade social da } \\
\text { universidade }\end{array}$ & 3,0 & 6,1 & 15,2 & 24,2 & 48,5 & 3,13 & 1,08 \\
\hline 6 & $\begin{array}{l}\text { Visão multidisciplinar das } \\
\text { IES }\end{array}$ & 6,1 & 6,1 & 21,2 & 18,2 & 45,5 & 3,00 & 1,26 \\
\hline
\end{tabular}

Fonte: Dados da pesquisa

Pelos dados apresentados, o conceito "Responsabilidade social da universidade" é um conceito mais usado por $72,7 \%$ pelos pesquisados. Seguindo este raciocínio, temos os conceitos "Normas e legislação vigentes nas IES” com 69,7\% e "Constituição de 1988" com $63,7 \%$.

É interessante notar que um quinto dos pesquisados afirmam que quase nunca ou nunca utilizam os conhecimentos abordados em "Constituição jurídica das universidades", “Constituição de 1998" e "Lei de Diretrizes e Bases".

O conteúdo "Responsabilidade social da universidade", da disciplina em questão, alcançou a maior média $(3,13)$ e desvio padrão de 1,08 .

O menor desvio padrão $(1,07)$ foi para o conceito "Normas e legislação vigentes nas IFES", com média de 3,00.

O conteúdo previsto para ser abordado na disciplina "Contabilidade Pública” e a freqüência com que os pesquisados utilizam esse conteúdo estão apresentados na Tabela 7. 
Tabela 7 - Distribuição das respostas de acordo com a freqüência de uso do conteúdo abordado em

Contabilidade Pública

\begin{tabular}{|c|c|c|c|c|c|c|c|c|}
\hline & Conteúdo & Nunca & $\begin{array}{l}\text { Quase } \\
\text { nunca }\end{array}$ & $\begin{array}{c}\text { Às } \\
\text { vezes }\end{array}$ & $\begin{array}{l}\text { Quase } \\
\text { sempre }\end{array}$ & Sempre & Média & $\begin{array}{l}\text { Desvio } \\
\text { padrão }\end{array}$ \\
\hline 1 & $\begin{array}{l}\text { Aspectos introdutórios da teoria da } \\
\text { contabilidade (objetivos, ativo, passivo, } \\
\text { receita, despesa, patrimônio, regime de } \\
\text { caixa X regime de competência) }\end{array}$ & 15,2 & 30,3 & 21,2 & 9,1 & 24,2 & 1,97 & 1,40 \\
\hline 2 & $\begin{array}{l}\text { Processo orçamentário (elaboração da } \\
\text { proposta, discussão, votação e aprovação } \\
\text { da lei orçamentária, execução, controle e } \\
\text { sua avaliação) }\end{array}$ & 18,2 & 30,3 & 21,2 & 9,1 & 21,2 & 1,85 & 1,40 \\
\hline 3 & $\begin{array}{l}\text { Execução orçamentária: } \\
\text { a) despesas (programação de } \\
\text { desembolso, licitação, empenho, } \\
\text { liquidação, pagamento, divida ativa, } \\
\text { restos a pagar). }\end{array}$ & 12,1 & 30,3 & 12,1 & 12,1 & 33,3 & 2,24 & 1,48 \\
\hline & $\begin{array}{l}\text { b) receitas (lançamento, arrecadação e } \\
\text { recolhimento). }\end{array}$ & 18,2 & 36,4 & 6,1 & 15,2 & 24,2 & 1,91 & 1,48 \\
\hline & Características da contabilidade pública: & & & & & & & \\
\hline 4 & $\begin{array}{l}\text { a) breve histórico, plano de contas e } \\
\text { tabela de eventos }\end{array}$ & 21,2 & 36,4 & 18,2 & 6,1 & 18,2 & 1,64 & 1,37 \\
\hline & $\begin{array}{l}\text { b) sistemas (financeiro, patrimonial, } \\
\text { orçamentário, de compensação, } \\
\text { lançamentos, demonstrações } \\
\text { contábeis). }\end{array}$ & 18,2 & 33,3 & 15,2 & 12,1 & 18,2 & 1,78 & 1,39 \\
\hline & $\begin{array}{l}\text { c) elaboração e análise, procedimentos } \\
\text { e demonstrações previstas na Lei de } \\
\text { Responsabilidade Fiscal. }\end{array}$ & 21,2 & 30,3 & 21,2 & 6,1 & 18,2 & 1,69 & 1,38 \\
\hline 5 & $\begin{array}{l}\text { Normas internacionais de contabilidade no } \\
\text { setor público }\end{array}$ & 36,4 & 33,3 & 12,1 & 6,1 & 12,1 & 1,24 & 1,33 \\
\hline
\end{tabular}

Fonte: Dados da pesquisa

O item mais utilizado, de acordo com os pesquisados, foi "Execução orçamentária: a) despesas (programação de desembolso, licitação, empenho, liquidação, pagamento, divida ativa, restos a pagar)", com $45,4 \%$.

"Características da contabilidade pública: a) breve histórico, plano de contas e tabela de eventos" foi menos utilizado por $75,8 \%$ dos pesquisados, enquanto $24,2 \%$ sempre utilizam "Execução orçamentária: b) receitas (lançamento, arrecadação e recolhimento)".

De acordo com a Tabela 7, em torno de um terço dos pesquisados informaram que quase nunca usam os conteúdos abordados nesta disciplina. Adicionalmente, $36,4 \%$ dos pesquisados informaram que nunca utilizaram o conteúdo relativo à "Normas internacionais de contabilidade no setor público". Tais fatos podem ter ocorrido devido aos conteúdos estarem relacionados com áreas de controle e finanças, em que apenas $6,04 \%$ dos pesquisados atuam.

"Execução orçamentária: a) despesas (programação de desembolso, licitação, empenho, liquidação, pagamento, divida ativa, restos a pagar)" atingiu a maior média entre todos os conceitos, com 2,24 e desvio padrão de 1,48. 
De acordo com os pesquisados, o menor desvio padrão foi para o conceito "Normas internacionais de contabilidade no setor público" com 1,33 e média 1,24.

O conteúdo previsto para ser abordado na disciplina "Planejamento, Administração e Gestão" e a freqüência com que os pesquisados utilizam esse conteúdo estão apresentados na Tabela 8.

Tabela 8 - Distribuição das respostas de acordo com a freqüência de uso do conteúdo abordado em Planejamento, Administração e Gestão.

\begin{tabular}{c|l|c|c|c|c|c|c|c}
\hline & \multicolumn{1}{|c|}{ Conteúdo } & Nunca & $\begin{array}{c}\text { Quase } \\
\text { nunca }\end{array}$ & $\begin{array}{c}\text { As } \\
\text { vezes }\end{array}$ & $\begin{array}{c}\text { Quase } \\
\text { sempre }\end{array}$ & Sempre & Média & $\begin{array}{c}\text { Desvio } \\
\text { Padrão }\end{array}$ \\
\hline 1 & $\begin{array}{l}\text { Fundamentos e evolução das teorias } \\
\text { da administração }\end{array}$ & 0 & 15,2 & 27,3 & 36,4 & 21,2 & 2,64 & 0,98 \\
2 & $\begin{array}{l}\text { Funções da administração (planejar, } \\
\text { organizar, dirigir e controlar). } \\
3\end{array}$ & 0 & 6,1 & 6,1 & 18,2 & 69,7 & 3,52 & 0,86 \\
& $\begin{array}{l}\text { Responsabilidade social e ética nas } \\
\text { organizações }\end{array}$ & 0 & 3,0 & 6,1 & 24,2 & 66,7 & 3,55 & 0,74 \\
4 & $\begin{array}{l}\text { Conceito de organização formal e } \\
\text { informal }\end{array}$ & 3,0 & 9,1 & 21,2 & 36,4 & 30,3 & 2,82 & 1,06 \\
& $\begin{array}{l}\text { Processo de tomada de decisão (tipos, } \\
\text { processo e condição para tomada de } \\
\text { decisão) }\end{array}$ & 0 & 6,1 & 9,1 & 27,3 & 57,6 & 3,36 & 0,88 \\
6 & $\begin{array}{l}\text { Planejamento (conceito, objetivos, } \\
\text { níveis, vantagens e limitações) } \\
7\end{array}$ & 0 & 6,1 & 18,2 & 24,2 & 51,5 & 3,21 & 0,95 \\
Estratégia (conceito, empresa X \\
organização empresarial) \\
$\begin{array}{l}\text { Planejamento e administração } \\
\text { estratégica: visão, missão, valores e } \\
\text { objetivos }\end{array}$ & 3,0 & 9,1 & 15,2 & 24,2 & 48,5 & 3,06 & 1,13 \\
\hline
\end{tabular}

Fonte: Dados da pesquisa

Na disciplina "Planejamento, Administração e Gestão" os conteúdos "Funções da administração (planejar, organizar, dirigir e controlar)" registram 69,7\% na categoria sempre usado, bem como "Conceitos responsabilidade social e ética nas organizações" aparece com $66,7 \%$, "Processo de tomada de decisão (tipos, processos e condição para tomada de decisão)" registra 57,6\%, "Planejamento (conceito, objetivos, níveis, vantagens e limitações)" surge com $51,5 \%$, no que se referem a conceitos sempre usados. Nestes conceitos a maior média foi obtida no conceito "Responsabilidade social e ética nas organizações", com 3,55 e um desvio padrão de 0,74 .

No que respeita ao "Conceito de organização formal e informal" e "Planejamento e administração estratégica (visão, missão, valores e objetivos)", estes surgem na pesquisa com $3,0 \%$ na freqüência como conceitos nunca usados. Estes conceitos apresentam média de 2,82 e 3,06, respectivamente. O desvio padrão para esses conceitos apresenta-se com 1,06 e 1,13, respectivamente. 
O conteúdo previsto para ser abordado na disciplina "Trabalho, Gestão e Subjetividade nas Organizações" e a freqüência com que os pesquisados utilizam esse conteúdo estão apresentados na Tabela 9.

Tabela 9 - Distribuição das respostas de acordo com a freqüência de uso do conteúdo abordado em Trabalho, Gestão e Subjetividade nas Organizações

\begin{tabular}{|c|c|c|c|c|c|c|c|c|}
\hline & Conteúdo & Nunca & $\begin{array}{l}\text { Quase } \\
\text { nunca }\end{array}$ & $\begin{array}{c}\text { Ass } \\
\text { vezes }\end{array}$ & $\begin{array}{l}\text { Quase } \\
\text { sempre }\end{array}$ & Sempre & Média & $\begin{array}{l}\text { Desvio } \\
\text { padrão }\end{array}$ \\
\hline 1 & $\begin{array}{l}\text { O trabalho no setor público a } \\
\text { partir do modelo pós-burocrático }\end{array}$ & 9,1 & 6,1 & 36,4 & 27,3 & 21,2 & 2,45 & 1,16 \\
\hline 2 & Modelos de gestão e o indivíduo & 3,0 & 12,1 & 15,2 & 39,4 & 30,3 & 2,82 & 1,09 \\
\hline 3 & $\begin{array}{l}\text { Gestão de qualidade total e sua } \\
\text { relação com RH }\end{array}$ & 0 & 12,1 & 18,2 & 36,4 & 33,3 & 2,91 & 1,00 \\
\hline 4 & Comunicação nas organizações & 6,1 & 0 & 9,1 & 27,3 & 57,6 & 3,30 & 1,06 \\
\hline 5 & $\begin{array}{l}\text { Qualidade e excelência no } \\
\text { atendimento aos clientes }\end{array}$ & 0 & 6,1 & 6,1 & 36,4 & 51,5 & 3,33 & 0,84 \\
\hline 6 & $\begin{array}{l}\text { Cultura organizacional } \\
\text { Relações de poder e }\end{array}$ & 3,0 & 3,0 & 12,1 & 42,4 & 39,4 & 3,12 & 0,95 \\
\hline 7 & $\begin{array}{l}\text { subjetividade dos indivíduos nas } \\
\text { organizações }\end{array}$ & 3,0 & 3,0 & 21,2 & 39,4 & 33,3 & 2,97 & 0,97 \\
\hline 8 & Sofrimento humano no trabalho & 3,0 & 6,1 & 18,2 & 36,4 & 36,4 & 2,97 & 1,03 \\
\hline 9 & Os sentidos do trabalho & 3,0 & 0 & 27,3 & 21,2 & 48,5 & 3,12 & 1,01 \\
\hline
\end{tabular}

Fonte: Dados da pesquisa

"Qualidade e excelência no atendimento aos clientes" alcançou 87,9\% dos que fazem uso no dia-a-dia de suas atividades, demonstrando, assim, ser um conceito bastante utilizado pelos pesquisados, porém, para $6,1 \%$ dos pesquisados o conceito é usado às vezes e para outros $6,1 \%$, quase nunca. Se considerarmos a importância do conceito para a imagem da organização e das áreas junto a seus clientes, seria necessário identificar as razões pelas quais o conceito não foi incorporado ao cotidiano das áreas às quais esses pesquisados estão vinculados. O conceito "Comunicação nas organizações" também foi indicado como bastante utilizado, com $84,9 \%$.

Os conceitos "Modelos de gestão e o indivíduo", "Gestão de qualidade total e sua relação com RH" e "Os sentidos do trabalho" são menos utilizados de acordo com 30,3\% dos pesquisados.

Pelos dados apresentados, o conceito "Sofrimento humano no trabalho" $(72,8 \%)$ quase sempre ou sempre é utilizado nas atividades diárias. Seria interessante investigar por que ocorre tal fato.

Com exceção do conteúdo "O trabalho no setor público a partir do modelo pósburocrático", em que quase metade dos pesquisados afirma ser um conceito utilizado quase sempre ou sempre, todos os outros conteúdos abordados na disciplina foram apontados como sendo quase sempre ou sempre utilizados por mais de $70 \%$ dos pesquisados. 
A maior média, segundo os dados da Tabela 9, foi 3,33 no conceito "Qualidade e excelência no atendimento aos clientes", com desvio padrão de 0,84 seguido dos conceitos "Cultura organizacional" e "Os sentidos do trabalho" com 3,12 e desvio padrão de 0,95 e 1,01 , respectivamente.

Pelos dados apresentados na disciplina "Trabalho, Gestão e Subjetividade nas Organizações", "O trabalho no setor público a partir do modelo pós-burocrático" foi o conteúdo que obteve o maior desvio padrão 1,16 com média de 2,45.

O conteúdo previsto para ser abordado na disciplina "Gestão Financeira Aplicada" e a freqüência com que os pesquisados utilizam esse conteúdo estão apresentados na Tabela 10.

Tabela 10 - Distribuição das respostas de acordo com a freqüência de uso do conteúdo abordado em Gestão Financeira Aplicada

\begin{tabular}{|c|c|c|c|c|c|c|c|c|}
\hline & Conteúdo & Nunca & $\begin{array}{l}\text { Quase } \\
\text { nunca }\end{array}$ & $\begin{array}{c}\text { Às } \\
\text { vezes }\end{array}$ & $\begin{array}{l}\text { Quase } \\
\text { sempre }\end{array}$ & Sempre & Média & $\begin{array}{l}\text { Desvio } \\
\text { padrão }\end{array}$ \\
\hline 1 & Princípios Fundamentais de finanças & 18,2 & 18,2 & 30,3 & 24,2 & 9,1 & 1,88 & 1,22 \\
\hline 2 & Valor do dinheiro no tempo & 15,2 & 18,2 & 27,3 & 21,2 & 18,2 & 2,09 & 1,31 \\
\hline 3 & $\begin{array}{l}\text { Conceitos e características de taxas } \\
\text { de juros, risco e retorno, custos e } \\
\text { liquidez }\end{array}$ & 24,2 & 15,2 & 30,3 & 3,0 & 27,3 & 1,94 & 1,50 \\
\hline 4 & $\begin{array}{l}\text { Benefício da educação (custo do } \\
\text { aluno e custo do setor público) }\end{array}$ & 18,2 & 12,1 & 24,2 & 12,1 & 33,3 & 2,30 & 1,49 \\
\hline 5 & $\begin{array}{l}\text { Características de finanças } \\
\text { comportamentais }\end{array}$ & 21,2 & 18,2 & 24,2 & 12,1 & 14,2 & 2,00 & 1,46 \\
\hline 6 & $\begin{array}{l}\text { Importância do conhecimento da } \\
\text { matemática financeira }\end{array}$ & 15,2 & 18,2 & 33,3 & 18,2 & 15,2 & 2,00 & 1,26 \\
\hline 7 & $\begin{array}{l}\text { O poder da economia e o risco de um } \\
\text { país }\end{array}$ & 24,2 & 21,2 & 33,3 & 3,0 & 18,2 & 1,70 & 1,36 \\
\hline 8 & $\begin{array}{l}\text { Contabilidade de custo (conceitos, } \\
\text { alocação, regime de caixa e } \\
\text { competência) }\end{array}$ & 15,2 & 18,2 & 30,3 & 18,2 & 18,2 & 2,06 & 1,30 \\
\hline 9 & $\begin{array}{l}\text { Características da economia da } \\
\text { informação }\end{array}$ & 18,2 & 21,2 & 21,2 & 27,3 & 12,1 & 1,94 & 1,30 \\
\hline
\end{tabular}

Fonte: Dados da pesquisa

Com base nas respostas dadas pelos pesquisados, verificou-se que apenas para a disciplina "Gestão Financeira Aplicada" o conceito de "Benefício da educação (custo do aluno e custo do setor público)" alcançou 33,3\% e em "Conceitos e características de taxas de juros, risco e retorno, custos e liquidez", 27,3\% na classificação sempre usa. Para "Valor do dinheiro no tempo", "O poder da economia e o risco de um país" e "Contabilidade de custo (conceitos, alocação, regime de caixa e competência) foram obtidos 18,2\% nessa mesma classificação. O conceito "Benefício da educação (custo do aluno e custo do setor público)" obteve a maior média, ou seja 2,30 e um desvio padrão de 1,49.

No que respeita à classificação nunca usam, "Conceitos e características de taxas de juros, risco e retorno, custos e liquidez" "O poder da economia e o risco de um país" 
alcançaram 24,2\%. E em "Valor do dinheiro no tempo", "Importância do conhecimento da matemática financeira", bem como "Contabilidade de custo (conceitos, alocação, regime de caixa e competência)" foram alcançados $15,2 \%$.

Nessa disciplina e em "Contabilidade Pública", comparando com as outras disciplinas, houve um maior número de pesquisados respondendo que nunca utilizou os conteúdos (entre $12,1 \%$ e $36,4 \%$ ). Isso talvez se deva à área de atuação dos pesquisados, como apontado anteriormente.

O conteúdo previsto para ser abordado na disciplina "Comportamento Organizacional" e a freqüência com que os pesquisados utilizam esse conteúdo estão apresentados na Tabela 11.

Tabela 11 - Distribuição das respostas de acordo com a freqüência de uso do conteúdo abordado em Comportamento Organizacional

\begin{tabular}{|c|c|c|c|c|c|c|c|c|}
\hline & Conteúdo & Nunca & $\begin{array}{l}\text { Quase } \\
\text { nunca }\end{array}$ & $\begin{array}{c}\text { Às } \\
\text { vezes }\end{array}$ & $\begin{array}{l}\text { Quase } \\
\text { sempre }\end{array}$ & Sempre & Média & $\begin{array}{l}\text { Desvio } \\
\text { padrão }\end{array}$ \\
\hline 1 & $\begin{array}{l}\text { Conceitos, teorias, abordagens e } \\
\text { sua aplicação em: } \\
\text { a) comprometimento } \\
\text { organizacional }\end{array}$ & 3,0 & 3,0 & 18,2 & 18,2 & 57,6 & 3,24 & 1,05 \\
\hline & b) satisfação no trabalho & 0 & 3,0 & 6,1 & 33,3 & 57,6 & 3,45 & 0,74 \\
\hline & c) motivação & 0 & 6,1 & 3,0 & 30,3 & 60,6 & 3,45 & 0,82 \\
\hline 3 & $\begin{array}{l}\text { Liderança: conceitos, tipos e sua } \\
\text { aplicabilidade }\end{array}$ & 0 & 3,0 & 12,1 & 27,3 & 57,6 & 3,39 & 0,81 \\
\hline 4 & $\begin{array}{l}\text { Equipes de trabalho: conceitos, } \\
\text { formação e desenvolvimento e sua } \\
\text { aplicação }\end{array}$ & 0 & 3,0 & 15,2 & 15,2 & 66,7 & 3,45 & 0,86 \\
\hline 5 & $\begin{array}{l}\text { Mudança organizacional: } \\
\text { conceitos, tipos e sua aplicação }\end{array}$ & 3,0 & 3,0 & 21,2 & 30,3 & 42,4 & 3,06 & 1,01 \\
\hline 6 & $\begin{array}{l}\text { Qualidade de vida e estresse: } \\
\text { conceitos e condições de trabalho }\end{array}$ & 0 & 3,0 & 15,2 & 27,3 & 54,5 & 3,33 & 0,84 \\
\hline
\end{tabular}

Fonte: Dados da pesquisa

Pelos dados obtidos, os conceitos "b) satisfação no trabalho" e "c) motivação" são mais usados por mais de $90 \%$ dos pesquisados e "Qualidade de vida e estresse: conceitos e condições de trabalho" por aproximadamente $82 \%$ dos pesquisados. Seria útil verificar a relação entre esses usos, se positiva ou não. É pertinente estudo futuro para tentar descobrir tal fato.

De acordo com os pesquisados, o conceito "Equipes de trabalho: conceitos, formação e desenvolvimento e sua aplicação" é um conteúdo sempre usado por $66,7 \%$ dos pesquisados.

"Liderança: conceitos, tipos e sua aplicabilidade" é um conceito usado por mais de $84 \%$ dos pesquisados e seguindo este raciocínio, "Comprometimento organizacional” aparece com $75 \%$. 
Todos os conteúdos da disciplina "Comportamento Organizacional” são usados por mais de $72 \%$ dos pesquisados. A média de todos os conteúdos abordados na disciplina “Comportamento Organizacional” ficou acima de 3,06. "Conceitos, teorias, abordagens e sua aplicação em: a) comprometimento organizacional” atingiu o maior desvio padrão 1,05 e média 3,24.

Os conteúdos previstos na disciplina "Direito Administrativo Aplicado" e a freqüência com que os pesquisados utilizam esse conteúdo estão apresentados na Tabela 12.

Tabela 12 - Distribuição das respostas de acordo com a freqüência de uso do conteúdo abordado em Direito Administrativo Aplicado

\begin{tabular}{|c|c|c|c|c|c|c|c|c|}
\hline & Conteúdo & Nunca & $\begin{array}{l}\text { Quase } \\
\text { nunca }\end{array}$ & $\begin{array}{c}\text { Às } \\
\text { vezes }\end{array}$ & $\begin{array}{l}\text { Quase } \\
\text { sempre }\end{array}$ & Sempre & Média & $\begin{array}{l}\text { Desvio } \\
\text { padrão }\end{array}$ \\
\hline 1 & $\begin{array}{l}\text { Direito administrativo: conceitos, função, } \\
\text { objeto e princípios }\end{array}$ & 3,0 & 9,1 & 18,2 & 27,3 & 42,4 & 2,97 & 1,11 \\
\hline 2 & $\begin{array}{l}\text { Poderes do Estado, Governo e } \\
\text { Administração }\end{array}$ & 9,1 & 9,1 & 21,2 & 27,3 & 33,3 & 2,67 & 1,27 \\
\hline 3 & $\begin{array}{l}\text { Características e princípios da } \\
\text { administração pública e privada }\end{array}$ & 6,1 & 0 & 15,2 & 39,4 & 36,4 & 3,03 & 1,05 \\
\hline 4 & $\begin{array}{l}\text { Características das entidades políticas, } \\
\text { políticas administrativas, órgãos e } \\
\text { agentes públicos }\end{array}$ & 3,0 & 9,1 & 15,2 & 27,3 & 45,5 & 3,03 & 1,11 \\
\hline 5 & $\begin{array}{l}\text { Poderes e deveres da administração } \\
\text { pública }\end{array}$ & 3,0 & 3,0 & 9,1 & 21,2 & 63,6 & 3,39 & 0,98 \\
\hline 6 & $\begin{array}{l}\text { Ato administrativo: conceitos, requisitos, } \\
\text { atributos, anulação, revogação, } \\
\text { vinculação e discricionariedade }\end{array}$ & 9,1 & 6,1 & 21,2 & 18,2 & 45,5 & 2,85 & 1,31 \\
\hline 7 & Licitação: conceitos, tipos e finalidade & 15,2 & 6,1 & 27,3 & 21,2 & 30,3 & 2,45 & 1,37 \\
\hline 8 & $\begin{array}{l}\text { Contrato administrativo: conceitos e } \\
\text { características }\end{array}$ & 15,2 & 12,1 & 9,1 & 24,2 & 36,4 & 2,56 & 1,48 \\
\hline 9 & $\begin{array}{l}\text { Princípios e características do regime } \\
\text { jurídico }\end{array}$ & 6,1 & 12,1 & 18,2 & 18,2 & 45,5 & 2,85 & 1,28 \\
\hline
\end{tabular}

Fonte: Dados da pesquisa

Tomando por base as respostas dos pesquisados, os conteúdos dessa disciplina, na classificação sempre usa, o conceito "Poderes e deveres da administração pública" obteve índice de 63,6\%, "Características das entidades políticas, políticas administrativas, órgãos e agentes públicos", obteve 45,5\%, "Direito administrativo: conceitos, função, objeto e princípios" alcançou índice de 42,4\%, "Características e princípios da administração pública e privada" obteve 36,4\%, e "Poderes do Estado, Governo e Administração" atingiu 33,3\%.

O conteúdo "Poderes e deveres da administração pública" obteve a maior média $(3,39)$ e desvio padrão de 0,98 .

Há 15,2\% dos pesquisados que informaram que nunca usam "Licitação:conceitos, tipos e finalidade". Este mesmo percentual aplica-se às "Contrato administrativo: conceitos e 
características". Esses conteúdos apresentaram média de 2,45 e 2,56, e desvio padrão de 1,37 e 1,48 , respectivamente.

O conteúdo previsto para ser abordado na disciplina "Métodos e Técnicas de Pesquisa na Organização" e a freqüência com que os pesquisados utilizam esse conteúdo estão apresentados na Tabela 13.

Tabela 13 - Distribuição das respostas de acordo com a freqüiência de uso do conteúdo abordado em Métodos e Técnicas de Pesquisa na Organização

\begin{tabular}{|c|c|c|c|c|c|c|c|c|}
\hline & Conteúdo & Nunca & $\begin{array}{l}\text { Quase } \\
\text { nunca }\end{array}$ & $\begin{array}{c}\text { Às } \\
\text { vezes }\end{array}$ & $\begin{array}{l}\text { Quase } \\
\text { sempre }\end{array}$ & Sempre & Média & $\begin{array}{l}\text { Desvio } \\
\text { padrão }\end{array}$ \\
\hline 1 & $\begin{array}{l}\text { Características da ciência, do } \\
\text { trabalho e da pesquisa científica }\end{array}$ & 12,1 & 21,2 & 12,1 & 21,2 & 33,3 & 2,42 & 1,44 \\
\hline 2 & $\begin{array}{l}\text { Normas para elaboração de um } \\
\text { trabalho científico }\end{array}$ & 15,2 & 12,1 & 24,2 & 6,1 & 42,4 & 2,48 & 1,50 \\
\hline \multirow[t]{4}{*}{3} & $\begin{array}{l}\text { Pesquisa científica (características e } \\
\text { classificacões) }\end{array}$ & 21,2 & 12,1 & 15,2 & 18,2 & 33,3 & 2,30 & 1,55 \\
\hline & a) pesquisa bibliográfica & 21,2 & 6,1 & 21,2 & 21,2 & 30,3 & 2,33 & 1,49 \\
\hline & $\begin{array}{l}\text { b) pesquisa quantitativa e } \\
\text { qualitativa }\end{array}$ & 15,2 & 27,3 & 15,2 & 9,1 & 33,3 & 2,18 & 1,51 \\
\hline & $\begin{array}{l}\text { c) tipos de pesquisa e objetivos } \\
\text { (survey, entrevista, focus group } \\
\text { e pesquisa documental) }\end{array}$ & 18,2 & 21,2 & 15,2 & 15,2 & 30,3 & 2,18 & 1,51 \\
\hline 4 & Elaboração do projeto de pesquisa & 27,3 & 12,1 & 15,2 & 9,1 & 36,4 & 2,15 & 1,65 \\
\hline 5 & Desenvolvimento de pesquisa & 27,3 & 15,2 & 9,1 & 15,2 & 33,3 & 2,12 & 1,65 \\
\hline 6 & Elaboração da monografia & 21,2 & 24,2 & 15,2 & 6,1 & 33,3 & 2,06 & 1,58 \\
\hline
\end{tabular}

Fonte: Dados da pesquisa

Pela característica que a disciplina "Métodos e Técnicas de Pesquisa na Organização" apresentou, os resultados desta pesquisa demonstraram que os conteúdos mais usados ficaram entre $42,4 \%$ a $54,5 \%$, e os que fazem pouco uso entre $45,4 \%$ a $57,7 \%$. Somente o conteúdo "Elaboração da monografia" teve a maior margem, com 60,6\% que utilizam menos e 39,4\% dos pesquisados usam mais este conceito.

A maior média $(2,48)$ ficou para o conceito "Normas para elaboração de um trabalho científico" com desvio padrão de 1,50, enquanto que "Características da ciência, do trabalho e da pesquisa científica" atingiu a média de 2,42, com desvio padrão de 1,44 e "Pesquisa científica: a) pesquisa bibliográfica” atingiu a média de 2,33 e desvio padrão de 1,49.

Dos conceitos "Pesquisa científica: c) tipos de pesquisa e objetivos (survey, entrevista, focus group e pesquisa documental)" e "Elaboração do projeto de pesquisa", 54,6\% dos pesquisados informou que faz pouco uso dos conteúdos. Seria interessante um aprofundamento de estudos para tentar descobrir por que isto ocorre, uma vez que nove pesquisados trabalham em atividade de apoio em área fim, dezesseis em área meio, três pessoas na área de suporte à administração superior, três em áreas técnicas e três envolvendo tanto a área acadêmica quanto a área administrativa da Instituição. 
Perguntados quanto à contribuição desta disciplina no dia-a-dia dos pesquisados, um quarto respondeu que estava relacionada diretamente com o projeto de monografia em lugar das atividades diárias.

Em relação ao grau de importância do conteúdo abordado nas disciplinas para uma melhor compreensão de sua realidade cotidiana, os dados estão apresentados na Tabela 14.

Tabela 14 - Grau de importância do conteúdo abordado, em cada uma das disciplinas, para a melhor compreensão da realidade cotidiana

\begin{tabular}{l|c|c|c|c}
\hline \multicolumn{1}{c|}{ Disciplina } & $\begin{array}{c}\text { Nenhuma } \\
\text { importância }\end{array}$ & $\begin{array}{c}\text { Pouco } \\
\text { importante }\end{array}$ & Importante & $\begin{array}{c}\text { Muito } \\
\text { importante }\end{array}$ \\
\hline Introdução à Gestão do Ensino Superior & 0 & 9,1 & 57,6 & 33,3 \\
Gestão de Pessoas & 0 & 6,1 & 54,5 & 39,4 \\
Direito Aplicado ao Ensino Superior & 0 & 15,2 & 51,5 & 33,3 \\
Contabilidade Pública & 6,1 & 33,3 & 39,4 & 21,2 \\
Planejamento, Administração e Gestão & 0 & 9,1 & 45,5 & 45,5 \\
Trabalho, Gestão e Subjetividade nas & 0 & 6,1 & 39,4 & 51,5 \\
Organizações & 0 & 36,4 & 42,4 & 21,2 \\
Gestão Financeira Aplicada & 0 & 0 & 36,4 & 63,6 \\
Comportamento Organizacional & 0 & 6,1 & 54,5 & 39,4 \\
Direito Administrativo Aplicado & 6,1 & 24,2 & 36,4 & 33,3 \\
Métodos e Técnicas de Pesquisas nas & \multicolumn{3}{c}{} \\
Organizações & & & & \\
\hline
\end{tabular}

Fonte: Dados da pesquisa

Em relação a "Introdução à Gestão do Ensino Superior", um total de 57,6\% entendeu que a disciplina é importante, $33.3 \%$ manifestaram que a consideram como muito importante e somente $9,1 \%$ a classificaram como um conhecimento de pouca importância.

A disciplina cujo conteúdo foi considerado como muito importante por um maior percentual de pesquisados foi "Comportamento Organizacional”, com 63,6\%. Também foi nessa disciplina em que não houve pesquisados que a classificassem como nenhum ou pouco importante.

O conteúdo das disciplinas "Gestão de Pessoas" e "Direito Administrativo Aplicado" apresentaram os mesmos índices, sendo que 6,1\% entendeu que é pouco importante, $54,5 \%$ é importante e para $39,4 \%$, muito importante.

Pelos índices apresentados na disciplina "Direito Aplicado ao Ensino Superior", a maioria dos pesquisados (51,5\%) considerou seu conteúdo importante, 33,3\% muito importante e para 15,2\% teve pouca importância na aplicabilidade diária.

As disciplinas em que o conteúdo foi classificado por $6,1 \%$ dos pesquisados como não tendo nenhuma importância foram "Contabilidade Pública" e "Métodos e Técnicas de Pesquisa na Organização". Apesar deste índice, em "Contabilidade Pública”, 39,4\% dos pesquisados consideram o conteúdo desta disciplina importante e 21,2\% como muito importante, porém é interessante lembrar que há pesquisados que informaram que esse 
conteúdo nunca foi utilizado. Talvez fosse melhor para a Instituição promover um curso de extensão para os funcionários que atuam nesta área.

Em referência ao conteúdo da disciplina "Planejamento, Administração e Gestão", os índices de importante e muito importante se igualaram, com um percentual de 45,5\% em cada um deles. Cerca de 9\% considerou o conteúdo pouco importante.

Mais da metade dos pesquisados $(51,5 \%)$ considera o conteúdo da disciplina “Trabalho, Gestão e Subjetividade nas Organizações" muito importante, 39,4\% importante e $6,1 \%$ de pouca importância para aplicabilidade em suas atividades diárias.

Em relação ao conteúdo da disciplina "Gestão Financeira Aplicada", obteve-se o maior índice de pesquisados $36,4 \%$ que o julgou ser de pouca importância, apesar de $42,4 \%$ apontá-lo como sendo importante e 21,2\% muito importante, porém, é interessante lembrar que vários pesquisados também informaram que esse conteúdo nunca foi utilizado.

Na Tabela 15 será destacada a média, em ordem decrescente, com referência ao grau de importância das disciplinas para a melhor compreensão da realidade cotidiana dos pesquisados, bem como os respectivos desvios-padrão. É importante lembrar que a escala varia de 0 a 3.

Tabela 15 - Média de importância das disciplinas para o uso cotidiano no trabalho e respectivo desvio-padrão

\begin{tabular}{l|c|c}
\hline \multicolumn{1}{c|}{ Disciplina } & Média & Desvio padrão \\
\hline Comportamento Organizacional & 2,64 & 0,48 \\
Trabalho, Gestão e Subjetividade nas Organizações & 2,47 & 0,61 \\
Planejamento, Administração e Gestão & 2,36 & 0,64 \\
Gestão de Pessoas & 2,33 & 0,59 \\
Direito Administrativo Aplicado & 2,33 & 0,59 \\
Introdução à Gestão do Ensino Superior & 2,24 & 0,60 \\
Direito Aplicado ao Ensino Superior & 2,18 & 0,67 \\
Métodos e Técnicas de Pesquisas nas Organizações & 1,97 & 0,90 \\
Gestão Financeira Aplicada & 1,85 & 0,74 \\
Contabilidade Pública & 1,76 & 0,85 \\
\hline
\end{tabular}

Fonte: Dados da pesquisa

É interessante notar que as disciplinas consideradas como menos importantes em relação às demais são as que têm conteúdo bastante específico: Contabilidade Pública, Gestão Financeira Aplicada e Métodos e Técnicas de Pesquisas nas Organizações. Mesmo assim os valores estão próximos de 2 , que indica serem disciplinas que foram consideradas importantes pelos pesquisados. 
Em relação à contribuição da disciplina "Introdução à Gestão do Ensino Superior" para o trabalho do pesquisado, foram apresentados 37 argumentos por 31 pesquisados, cujas respostas categorizadas são:

- Adequar o Ensino Superior no Hospital Escola (1);

- Compreender as necessidades de se ter um ensino que atenda a maior quantidade de egressos do $2^{\circ}$ grau (1);

- Aumentar o conhecimento intelectual (2);

- Conhecer a evolução das IES e sua importância para a sociedade; (15)

- Conhecer a situação do Ensino Superior e suas dificuldades; (1)

- Conhecer a situação do Ensino Superior e suas tendências; (2)

- Ter consciência sobre os objetivos, missão e política da Instituição, necessários ao desenvolvimento das tarefas; (1)

- Reconhecer a importância do serviço e do servidor público como cidadão; (1)

- Melhorar o conhecimento para tomar decisões com mais segurança; (1)

- Contribuir para o trato com alunos e professores; (2)

- Manter relacionamentos com a sociedade buscando soluções dos seus problemas; (1).

- Reconhecer e orientar a clientela usuária dos serviços oferecidos pela unidade; (5)

Alguns argumentos não tinham relação com a pesquisa e um pesquisado destacou o objetivo do curso. Essas respostas não foram consideradas na pesquisa.

Em relação à contribuição da disciplina “Gestão de Pessoas" para o trabalho do pesquisado, foram apresentados 39 argumentos por 31 pesquisados, cujas respostas categorizadas são:

- Exercer gerência sobre as pessoas é a tarefa mais importante de todo gestor; (1)

- Adquirir e influenciar na confiança dos subordinados em relação com o comprometimento com o trabalho; (3)

- Aprender a lidar com os colaboradores de forma democrática, respeitável e equilibrada; (2)

- As habilidades apreendidas fizeram com que eu cometesse menos erros em meu trabalho;

- Obter conhecimentos para avaliar o desempenho da equipe, necessidade de treinamento, dentre tantos outros; (2)

- Identificar os problemas na equipe de trabalho (2)

- Contribuir na valorização das pessoas e nas relações humanas; (4) 
- Foi importante para a correção de posturas na unidade, com destaque para a área de ergonomia, competências e gestão de desempenho; (1)

- Ter melhor noção do papel do gerente e percepção dos aspectos que podem influenciar os resultados da organização; (9)

- Tem me orientado no sentido de selecionar pessoas que irão assumir atividades em determinado setor; (1)

- Os conteúdos são sempre consultados para subsidiar decisões na área de atuação; (1)

- Pensar melhor como dirigente; (1)

- Ter visão da importância das pessoas e suas contribuições dentro da organização; (1)

- Tem contribuído na administração de conflitos; (1)

- Repensar a questão da avaliação de desempenho; (2)

- Identificar as mudanças na organização de forma participativa; (1)

- Identificar os talentos focando um melhor aproveitamento humano; (1).

- Foi a disciplina que mais contribuiu para a atividade. (1)

Apesar da maioria considerar que esta disciplina foi de grande valia, dois pesquisados relataram que "não contribuiu em nada para o meu setor" e "abordagem teórica da disciplina não tem aplicabilidade de $100 \%$ no cotidiano do setor", sendo que o primeiro pesquisado não tem subordinado e trabalha em área técnica e o segundo não respondeu às questões relativas a dados demográficos e funcionais.

Outras respostas estavam relacionadas com o objetivo do curso e não foram reproduzidas aqui.

Em relação à contribuição da disciplina "Direito Aplicado ao Ensino Superior" para o trabalho do pesquisado, foram apresentados 34 argumentos por 31 pesquisados, cujas respostas categorizadas são:

- Ampliar a visão de competência e de responsabilidade social das IFES; (1)

- Demonstrar segurança para a tomada de decisões na área jurídica; (2)

- Aplicar os princípios constitucionais e normas vigentes nos processos disciplinares; (2)

- Conhecer melhor a legalidade dos processos e aspectos jurídicos da Instituição; (10)

- Ter maior segurança para realização dos processos de compras e licitações;(1)

- Orientar quanto aos procedimentos na elaboração de projetos; (1)

- Contribuir para a formação da cidadania; (1)

- Contribuir para a melhoria na qualidade do desempenho das atividades. (3) 
Dois pesquisados responderam que a disciplina "Direito Aplicado ao Ensino Superior" não tem relação com as atividades do setor e um terceiro alegou que teve pouca contribuição em suas atividades diárias. Alguns focaram o objetivo do curso e não foram considerados e três pesquisados destacaram a importância da disciplina.

Em relação à contribuição da disciplina "Contabilidade Pública" para o trabalho do pesquisado, foram apresentados 37 argumentos por 30 pesquisados, cujas respostas categorizadas são:

- Elaborar custos nas unidades; (1)

- Compreender os processos de compras em órgão público; (1)

- Elaborar planilhas financeiras, observando a Lei e Responsabilidade Fiscal; (1)

- Interpretar os registros de transações financeiras; (6)

- Entender a gestão de recursos financeiros captados pela Instituição; (2)

- Ter noção do complexo mundo da contabilidade pública. (2)

Três pessoas responderam que a matéria foi importante para área que atuam, sendo que uma destacou "pena que a turma não gostou", duas definiram ser uma disciplina de difícil compreensão, cerca de quatorze pesquisados responderam que não tem aplicabilidade na atividade cotidiana e algumas respostas não foram compreendidas.

Em relação à contribuição da disciplina "Planejamento, Administração e Gestão" para o trabalho do pesquisado, foram apresentados 33 argumentos por 30 pesquisados, cujas respostas categorizadas são:

- Administrar e ampliar os conhecimentos das atividades diárias e gerenciais; (8)

- Compreender as várias formas de administrar e como é fundamental a gestão do planejamento estratégico; (1)

- Contribuir para uma melhor organização do setor; (2)

- Estabelecer e definir planos, estratégias, metas e reavaliar os projetos do departamento; (4)

- Focar melhor os resultados; (1)

- Confirmar a importância de planejar e administrar para ter um resultado satisfatório; (2)

- Melhorar a organização visando à eficiência e eficácia nas rotinas de trabalho; (2)

- Planejar as compras da unidade; (1)

- Planejar, estipular metas e conferir resultados; (1)

- Essencial importância na tomada de decisões visando atingir os meios propostos; (4) 
- Estabelecer e definir planos (1).

Um pesquisado respondeu que usa com freqüência esta disciplina, outro não contribuiu para o setor em que trabalha, um terceiro informou que o tema é relevante e útil se fosse aplicado em conjunto com a administração superior e as chefias e alguns destacaram a importância da disciplina para o setor em que trabalha e para a organização.

Em relação à contribuição da disciplina "Trabalho, Gestão e Subjetividade nas Organizações" para o trabalho do pesquisado, foram apresentados 33 argumentos por 29 pesquisados, cujas respostas categorizadas são:

- Compreender a minha atuação enquanto servidor público; (1)

- Conhecer o próximo e suas angústias frente aos desafios e condições de trabalho; (1)

- Contribuir nos processos de mudança e aperfeiçoamento de paradigmas; (1)

- Entender melhor as relações de trabalho; (8)

- Evidenciar o potencial humano para melhor atender aos usuários; (2)

- Obter a excelência no atendimento e na comunicação do setor; (2)

- Facilitar a visão organizacional com respeito à comunicação, relações humanas e feedback; (1)

- Reconhecer a importância dos aspectos humanos e organizacionais, facilitando integração com os demais setores da Instituição; (1)

- Melhorar as condições de trabalho dos nossos colegas; (1)

- Repensar em mudanças no setor como qualidade de vida; (3)

- Ter sensibilidade para conhecer e conviver com as diferenças; (1)

- Ter maior esclarecimento para entender a área onde atuo; (1)

- Compreender as situações durante a gestão dos desafios da Instituição; (1)

- Compartilhar com outras unidades no desenvolvimento de atividades comuns. (1)

Um respondente escreveu que não aplica os conteúdos ministrados nesta disciplina, outro informou que utiliza os conteúdos para subsidiá-lo em debates importantes. Um pesquisado respondeu que utiliza e propõe os temas que aprendeu na disciplina no seu setor e o resultado tem sido positivo. Sua aplicabilidade depende da chefia superior foi à contribuição de outro pesquisado e alguns destacaram a importância quanto ao uso dos conteúdos desta disciplina. 
Em relação à contribuição da disciplina Gestão Financeira Aplicada para o trabalho do pesquisado, foram apresentados 32 argumentos por 29 pesquisados, cujas respostas categorizadas são:

- Apurar custos dos serviços no setor; (2)

- Compreender a importância de gerir bem os recursos financeiros para alcançar objetivos e metas; (2)

- Contribuir para melhor análise na aplicação de escassos recursos para a unidade; (1)

- Entender como e quando aplicar recursos, visando um melhor aproveitamento dos mesmos;

- Evidenciar o valor do dinheiro no tempo, risco e retorno para melhor gerenciamento da área;

- Entender melhor o mercado; (1)

- Avaliar os comportamentos financeiros da Instituição; (1)

- Mostrar como se posicionar quanto aos gastos financeiros; (1)

- Ajudar na análise de custos hospitalares; (1)

- Contribuir na previsão de custos; (1)

-Auxiliar na elaboração de planilhas sobre custos de equipamentos. (1)

Um pesquisado informou que a disciplina foi muito importante para a compreensão e realização do trabalho no setor, três declararam que é bastante útil na vida privada, seis dos pesquisados responderam que não utilizam nas atividades do setor e seis têm pouca aplicabilidade nas atividades cotidianas. Aquisição de conhecimentos foi a resposta de um pesquisado e outro relatou a importância sobre a compreensão geral do universo financeiro.

Em relação à contribuição da disciplina "Comportamento Organizacional” para o trabalho do pesquisado, foram apresentados 35 argumentos por 30 pesquisados, cujas respostas categorizadas são:

- Melhorar as reuniões na unidade que passaram a focar mais o bem estar dos colaboradores; (1)

- Entender melhor as relações interpessoais no trabalho; (1)

- Contribuir para melhorar contatos entre colaboradores quanto à motivação e comportamento com a Instituição; (1)

- Facilitar o relacionamento interpessoal e motivacional; (1)

- Fator de motivar e ser motivado no ambiente de trabalho; (1) 
- Identificar a importância na valorização do comportamento humano; (1)

- Observar que o comprometimento ajuda no desempenho das atividades; (2)

- Otimizar as relações de trabalho; (7)

- Ajudar nas resistências dos funcionários quando envolve mudança organizacional; (2)

- Gerenciar equipe, proporcionando qualidade e melhores condições de trabalho; (5)

- Ter compreensão da importância sobre as informações que passo à comunidade em geral; (1)

- Obter novo sentido para o serviço público; (1)

Um pesquisado informou que há grande satisfação pessoal quando o trabalho é desempenhado com o grau de autonomia, identidade da tarefa e feedback, três relataram que fazem uso diariamente dos conceitos dessa disciplina e outras respostas não foram consideradas para esta pesquisa.

Em relação à contribuição da disciplina "Direito Administrativo Aplicado" para o trabalho do pesquisado, foram apresentados 26 argumentos por 24 pesquisados, cujas respostas categorizadas são:

- Compreender as relações entre a Instituição, as empresas e suas parcerias; (1)

- Compreender os princípios administrativos que regem a administração pública; (1)

- Entender melhor os procedimentos relacionados aos processos; (1)

- Gerir contratos e licitações com qualidade, transparência e em observância aos preceitos legais que regem o Estado e a administração; (1)

- Melhorar informações para dirimir questionamentos no desenvolvimento das atividades do setor; (1)

- Adquirir conhecimentos na tomada de decisão quanto à análise de convênios e contratos; (3)

- Compreender os direitos e deveres como cidadão e servidor público; (3)

- Melhorar os conhecimentos na área de pregoeiro; (1)

- Fornecer elementos que ajudam nas decisões (1).

Somente um pesquisado respondeu que esta disciplina é pouco aplicada na área de atuação, três pessoas relataram que é essencial para quem gerencia, ajuda no desenvolvimento das atividades e está implícito no cotidiano do trabalho, outro pesquisado relatou que é a base de ações do servidor público. A qualidade do meu trabalho melhorou foi a resposta de outro 
pesquisado, alguns destacaram a importância desta disciplina e outras respostas focaram o objetivo do curso.

Em relação à contribuição da disciplina "Métodos e Técnicas de Pesquisas nas Organizações" para o trabalho do pesquisado, foram apresentados 32 argumentos por 30 pesquisados, cujas respostas categorizadas são:

- Aplicar no desenvolvimento de projetos, relatórios e pesquisa; (3)

- Efetuar pesquisa de temas relacionados a custos; (1)

- Contribuir como modelo para se trabalhar dados gerenciais; (1)

- Elaborar projetos, com qualidade, de interesse da Instituição; (1)

- Orientar à clientela da área quanto a elaboração de projetos; (1)

- Ajudar nas tarefas administrativas (3).

Sete pessoas responderam que esta disciplina foi importante para elaboração da monografia, quatro informaram que foi de pouco uso para a unidade e três pesquisados concluíram que é uma matéria essencial e muito importante na vida profissional. Um pesquisado expressou que a disciplina "Métodos e Técnicas de Pesquisas nas organizações" é o livro de bolso para as outras disciplinas e para o nosso dia-a-dia, um respondeu que não se aplica no seu dia-a-dia e outras respostas não foram consideradas nesta pesquisa.

Perguntados se gostariam de compartilhar alguma outra informação, eis as respostas categorizadas:

- Curso excelente. Penso em continuar estudando.

- As disciplinas são usadas no trabalho quase que diariamente e com certeza melhorou em muito a qualidade do trabalho realizado;

- As disciplinas foram importantes para tentativa de melhorias com meus subordinados;

- Dos conteúdos ministrados no curso, na sua maioria são aplicados no trabalho do setor, o que melhorou muito a qualidade do trabalho realizado;

- Excelente curso. A Instituição está de parabéns pela iniciativa;

- Fazer chegar na administração superior os resultados desta pesquisa;

- Louvor à equipe, aos docentes e técnico-administrativos envolvidos na concepção e implantação de um curso de tamanha envergadura, permitindo importante aprendizado em termos de qualificação e enriquecimento profissional e pessoal; 
- O curso contribuiu para melhorar a qualidade de trabalho e com isso todos ganham: a universidade, os funcionários e a comunidade;

- O curso de especialização contribuiu de forma extraordinária, ampliando as novas possibilidades com grandes resultados;

- O curso foi importantíssimo e muito tem ajudado na melhoria do desempenho profissional;

- O curso foi muito bom, mesmo não fazendo uso de determinados conteúdos, é importante que o servidor esteja qualificado para assumir funções futuras;

- O curso foi importante para o crescimento pessoal e profissional. Poderia proporcionar um trabalho junto às chefias para um melhor aproveitamento do que foi adquirido pelo servidor;

- O curso permite uma visão da Instituição. Todos deveriam ter acesso para melhor compreensão das dificuldades e conhecer a instituição em que trabalha;

- Pesquisa importante para os dirigentes refletirem sobre o desenvolvimento das unidades e ajudarmos ao desenvolvimento do todo, que é o nosso interesse maior;

- Seria interessante se o curso fosse essencialmente voltado para a gestão universitária. 


\section{5 - Conclusão e Considerações Finais}

O objetivo desta pesquisa foi avaliar o impacto em profundidade do Curso de Especialização em Desenvolvimento Gerencial, em sua $1^{\text {a }}$ turma, no que respeita aos conteúdos ministrados e sua aplicabilidade na unidade de trabalho dos egressos.

As contribuições deste estudo residem na idéia de que a mesma venha a fornecer subsídios ao aprimoramento do Curso, contribuindo significativamente para estudos futuros voltados aos temas de aprendizagem nas organizações, no intuito de avaliar a profundidade de capacitação e qualificação de seus servidores.

"Conceitos e objetivos do ensino superior público" e "Conceitos e objetivos do serviço público" são os mais usados por 79,0\% e 75,8\% dos pesquisados, respectivamente. O conceito "Políticas de funcionamento das IES (desafios e perspectivas)" foi menos usado, com 45,5\%, e "Características das IES e das universidades brasileiras (criação, concepção, missão, objetivos, política, finalidades)" surge com 51,5\%.

Os "Conceitos de gestão de pessoas, teorias e abordagens" e "Aspectos que influenciam os resultados organizacionais" aparecem com 81,8\% e 78,7\%, respectivamente, como conceitos mais usados. Os conteúdos menos usados foram "Características de remuneração e produtividade", 63,6\%, e "Características que influenciam relações sindicais e trabalhistas", 59,5\%.

$\mathrm{Na}$ classificação mais usado, com 72,7\%, aparece o conceito "Responsabilidade social da universidade". Conceito "Constituição jurídica das universidades" foi o menos usado por $60,6 \%$ dos pesquisados.

"Execução orçamentária: despesas (programação de desembolso, licitação, empenho, liquidação, pagamento, dívida ativa, restos a pagar)" é o conceito mais usado por $45,4 \%$ dos pesquisados. "Elaboração e análise, procedimentos e demonstrações previstas na Lei de Responsabilidade Fiscal" foi menos utilizado por $72,7 \%$.

O conceito mais usado, com 90,9\%, foi "Responsabilidade social e ética nas organizações", e o menos usado por 15,2\% dos pesquisados é "Processo de tomada de decisão (tipos, processo e condição para tomada de decisão)".

Mais usado por $87,9 \%$ foi o conceito "Qualidade e excelência no atendimento aos clientes. $18,1 \%$ dos pesquisados apontaram "Cultura organizacional" como conceito menos utilizado. 
"Benefício da educação (custo do aluno e custo do setor público)" é quase sempre ou sempre utilizado por $45,4 \%$ dos pesquisados, sendo que "O poder da economia e o risco de um país" é menos utilizado por 78,7\%.

"Satisfação no trabalho" e "Motivação" são mais usados por mais de $90 \%$ dos pesquisados e "Liderança: conceitos, tipos e sua aplicabilidade" é um conceito menos usado por $15,1 \%$.

O conceito "Poderes e deveres da administração pública" é mais utilizado por 84,8\%, enquanto "Características e princípios da administração pública e privada" é menos utilizado por $21,3 \%$.

"Pesquisa científica (características e classificações)" é mais utilizado por 51,5\%, enquanto "Características da ciência, do trabalho e da pesquisa científica" é menos utilizado por $45,4 \%$.

Os conteúdos da disciplina "Comportamento Organizacional” foram mais usados por mais de $72 \%$ dos pesquisados. Também foi nesta disciplina que não houve menção na classificação nenhum ou pouco importante. "Funções da administração (planejar, organizar, dirigir e controlar)" é sempre usado por 69,7\% dos pesquisados. "Comunicação nas organizações" foi apontada como bastante utilizado por $84,9 \%$.

O grau de importância nos conteúdos abordados nas disciplinas, como muito importante, foi $63.6 \%$ em "Comportamento Organizacional” seguido da disciplina "Trabalho, gestão e Subjetividade ns Organizações" com 51,5\% dos pesquisados.

Recomenda-se investigação mais aprofundada para avaliar por que os conceitos "Características de remuneração e produtividade", "Características que influenciam relações sindicais e trabalhistas", "Segurança, medicina do trabalho e saúde ocupacional" e "Conceitos de recrutamento, seleção e suas características" são menos utilizados por mais de $53 \%$ dos pesquisados.

Destaque também é dado à disciplina "Direito Aplicado ao Ensino Superior", constante da Tabela 6, no que respeita aos tópicos "Constituição jurídica das universidades", "Constituição de 1998" e "Lei de Diretrizes e Bases", em que um quinto dos pesquisados afirmam que quase nunca ou nunca utilizam os conhecimentos abordados. Adicionalmente, em "Contabilidade Pública", aproximadamente um terço dos pesquisados informaram que quase nunca usam os conteúdos abordados nesta disciplina. "Sofrimento humano no trabalho" quase sempre ou sempre é usado nas atividades diárias $(72,8 \%)$, bem como o conceito "Qualidade de vida estresse: conceitos e condições de trabalho" é utilizado por 
aproximadamente $82 \%$ dos pesquisados. Seria interessante investigar a causa de tais incidências.

Tomando-se por base os dados da pesquisa, percebe-se que o treinamento foi considerado positivo pelos pesquisados, uma vez que muitos informaram usar de modo freqüente os conteúdos abordados. Observou-se também que a freqüência de uso dos conteúdos do curso pelos egressos é situacional, ocorrendo na medida em que surgem oportunidades de sua aplicação e das características das atividades da sua unidade de lotação. Percebeu-se, pelos dados apresentados, que houve significativa transferência de aprendizagem nos conteúdos abordados. É possível que os treinados tenham relatado um maior impacto das disciplinas do curso como forma de valorizar as habilidades adquiridas frente à organização.

Presume-se que os resultados desta pesquisa sejam capazes de permitir maior integração entre pesquisa e prática, bem como sugerir novas investigações sobre o tema objeto deste estudo, no sentido de encontrar evidências de que o treinamento com objetivos relevantes para os objetivos estratégicos da organização tem maior impacto em profundidade no trabalho que possa traduzir-se em estratégia institucional e contribuir para o aperfeiçoamento da gestão na Universidade de Brasília.

Em função dos resultados apresentados na pesquisa recomenda-se continuar o investimento em desenvolvimento gerencial, como forma de criar uma cultura organizacional permanente e contínua de qualificação, que contribua para o aumento de competências individuais dos servidores. Para estudos futuros, recomenda-se a realização de avaliação em profundidade e de amplitude junto a pares e gerentes dos egressos do curso. 


\section{REFERÊNCIAS}

ABBAD. G. S. Um modelo integrado de avaliação do impacto do treinamento no trabalho - IMPACT. 1999. 262f. Tese (Doutorado em Psicologia) - Instituto de Psicologia, Universidade de Brasília, Brasília, 1999.

Medidas de avaliação de procedimentos, processos e apoio instrucionais em TD\&E. In: BORGES-ANDRADE, J. E.; ABBAD, G. S.; MOURÃO, L. e colaboradores. Treinamento, desenvolvimento e educação em organizações e trabalho: fundamentos para a gestão de pessoas. Porto Alegre: Artmed, 2006. cap. 22.

ABBAD, G.S.; BORGES-ANDRADE, J.E. Aprendizagem humana em organizações de trabalho. In: ZANELLI, José Carlos; BORGES-ANDRADE, Jairo Eduardo e BASTOS, Antonio Virgílio Bittencourt (Orgs.) Psicologia, organizações e trabalho no Brasil. Porto Alegre: Artmed, 2004. cap.7, p. 237-257.

ABBAD, G.S.; FREITAS, I.A.; PILATI, R. Contexto de trabalho, desempenho competente e necessidades em TD\&E. In: BORGES-ANDRADE, J. E.; ABBAD, G. S.; MOURÃO, L. e colaboradores. Treinamento, desenvolvimento e educação em organizações e trabalho: fundamentos para a gestão de pessoas. Porto Alegre: Artmed, 2006. cap. 12.

BORGES-ANDRADE, J. E.; ABBAD, G. S. Treinamento no Brasil: reflexões sobre suas pesquisas. Revista de Administração, USP, p.112-125, 1996.

BORGES-ANDRADE, J.E. Treinamento de pessoal: em busca de conhecimento e tecnologias relevantes para as organizações brasileiras. In: TAMAYO, A.; BORGES-ANDRADE J.E. \& Codo W. (Orgs.) Trabalho, organizações e cultura. São Paulo: Cooperativa de Autores Associados. 1997. p.129-149.

BORGES-ANDRADE, J. E. Desenvolvimento de medidas em avaliação de treinamento. Estudos de Psicologia, Brasília, 7 (número especial), 2002.

Avaliação integrada e somativa em TD\&E. In: BORGES-ANDRADE, J. E.; $\overline{\mathrm{ABBAD}}$, G. S.; MOURÃO, L. e colaboradores. Treinamento, desenvolvimento e educação em organizações e trabalho: fundamentos para a gestão de pessoas. Porto Alegre: Artmed, 2006. cap. 17.

COSTA, M. A. F. da. Metodologia da Pesquisa: conceitos e técnicas. Rio de Janeiro: Interciência, 2001.

DANTAS, P. V. S. O impacto do curso de desenvolvimento gerencial da UnB no trabalho dos participantes. Estágio supervisionado em administração. Faculdade de Economia, Administração, Contabilidade e Ciência da Informação e Documentação. UnB, Out. 2006.

FRANCO, M. L. P. B. Análise de conteúdo. Brasília: Plano, 2003. 
FREITAS, I. A. Impacto de treinamento nos desempenhos do indivíduo e do grupo de trabalho: suas relações com crenças sobre o sistema de treinamento e suporte à aprendizagem contínua. 2005. 278 f. Tese (Doutorado em Psicologia) - Instituto de Psicologia, Universidade de Brasília, Brasília, 2005.

FREITAS, I. A. et. al. Medidas de impacto de TD\&E no trabalho e nas organizações. In: BORGES-ANDRADE, J. E.; ABBAD, G. S.; MOURÃO, L. e colaboradores. Treinamento, desenvolvimento e educação em organizações e trabalho: fundamentos para a gestão de pessoas. Porto Alegre: Artmed, 2006. cap. 24.

GASKELL, G. Entrevistas individuais e grupais. In: BAUER, M. W. Pesquisa qualitativa com texto, imagem e som: um manual prático. Petrópolis, RJ: Vozes, 2002. p. 64-88.

GRANJEIRO, J. W. Administração de recursos humanos. Brasília: Vest-Com, 1999.

HAMBLIN, A. C. Avaliação e controle do treinamento. São Paulo: McGraw-Hill do Brasil, 1978.

MIRANDA, N.A. de, (Org.) Plano anual de atividade - FUB, 2005: orçamento programa interno. Universidade de Brasília. Brasília, 2005.

ODELIUS, C. C. Administração de pessoas no limiar do século XXI: uma análise retrospectiva e algumas recomendações a respeito da atuação em recrutamento, seleção, treinamento e desenvolvimento. Apresentado no Seminário Nacional de Recursos Humanos: uma nova visão para o terceiro milênio. CEBRAD, Brasília. Out/1999.

Acompanha texto.

OLIVEIRA Jr., M. M. Competências essenciais e conhecimento na empresa. In: FLEURY, M. T. L.; OLIVEIRA JR., M. M. Integrando aprendizagem, conhecimento e competências. São Paulo: Alves, 2001. p. 121-156.

OLIVEIRA, M. R. C. T.; ITUASSU, C. T. Uma análise dos impactos do treinamento e desempenho de profissionais e gerentes. Dissertação (Mestrado em Administração de Empresas) - Universidade Federal de Minas Gerais. Minas Gerais, 2003.

PANTOJA, M. J. et al. Valores, suporte psicossocial e impacto do treinamento no trabalho. Estudos de Psicologia, Brasília, v. 10, n.2, set. 2005.

PILATI, R. História e importância de TD\&E. In: BORGES-ANDRADE, J. E.; ABBAD, G. S.; MOURÃO, L. e colaboradores. Treinamento, desenvolvimento e educação em organizações e trabalho: fundamentos para a gestão de pessoas. Porto Alegre: Artmed, 2006. cap. 8.

PILATI, R.; BOGES-ANDRADE, J. E. Estudo empírico dos antecedentes de medidas de impacto do treinamento no trabalho. Psicologia, Teoria e Pesquisa, Brasília, v. 20 n.1 jan./abr.2004. 
. Estratégias para aplicação no trabalho do aprendido em treinamento: proposição conceitual e desenvolvimento de uma medida. Psicologia: Reflexão e Crítica, Brasília, abr.2005, v.18 n. 2, p. 207-214.

. Construção de medidas e delineamentos em avaliação de TD\&E. In: BORGESANDRADE, J. E.; ABBAD, G. S.; MOURÃO, L. e colaboradores. Treinamento, desenvolvimento e educação em organizações e trabalho: fundamentos para a gestão de pessoas. Porto Alegre: Artmed, 2006. cap. 18.

POLITZER, G.et. al. Princípios fundamentais de filosofia. São Paulo: Hemus, 1991.

ROCHA, A. F. Evolução do trabalho e da tecnologia e seus impactos sobre a educação e a qualidade do trabalhador: uma abordagem teórica. Dissertação (Mestrado em Educação Tecnológica) - Centro Federal de Educação e Tecnológica de Minas Gerais. Belo Horizonte, 1999.

SALLORENZO, L. H. Avaliação de impacto de treinamento no trabalho: analisando e comparando modelos de predição. Dissertação (Mestrado em Psicologia) - Instituto de Psicologia, Universidade de Brasília, Brasília, 2000.

SILVA, A. A. R.; MORAES, L. F. R. Avaliação de resultados de treinamento no setor público: um estudo de caso no BDMG. In: XXVIII Anais do ENANPAD 2004. Curitiba, 2004.

SOUZA, E. C. L de. Módulo Integrado V: Gestão de organizações de aprendizagem. Serviço social da indústria - SESI, Universidade de Brasília - UnB, Organização das Nações Unidas para Educação Ciência e Cultura - UNESCO. Brasília - DF, 2001.

TOHÁ, C.; SOLARI, R. A modernização do estado e a gerência pública. Revista do Serviço Público. ENAP - Brasília - Ano 48, no 3 - set./dez., 1997.

Universade de Brasília. Secretaria de Recursos Humanos. Projeto de criação do curso de especialização em desenvolvimento gerencial. Brasília. 2005.

VARGAS, M. R. M.; ABBAD, G. S. Bases conceituais em treinamento, desenvolvimento e educação - TD\&E. In: BORGES-ANDRADE, J. E.; ABBAD, G. S.; MOURÃO, L. e colaboradores. Treinamento, desenvolvimento e educação em organizações e trabalho: fundamentos para a gestão de pessoas. Porto Alegre: Artmed, 2006. cap. 7.

VERGARA, S. C. Começando a definir a metodologia. In: Projetos e relatórios de pesquisa em administração. São Paulo: Atlas, 2000. cap. 4. 
APÊNDICE A 
Nome do participante do treinamento

Unidade de lotação

Questionário de Avaliação de Impacto em Profundidade do Curso de Especialização em Desenvolvimento Gerencial, Reação, Suporte à Transferência de Aprendizagem e Objetivos Alcançados.

\section{Instruções}

Este questionário é parte de uma pesquisa que está sendo realizada junto à $1^{\mathrm{a}}$ turma do Curso de Especialização em Desenvolvimento Gerencial oferecido aos gestores da Universidade de Brasília e busca avaliar a percepção dos participantes quanto ao impacto das várias disciplinas em seu dia-a-dia.

Para cada uma das disciplinas ministradas no curso são levantados três aspectos: freqüência de uso, importância para a atuação cotidiana e como o conteúdo tem contribuído para o seu trabalho.

Leia com atenção o conteúdo das afirmativas e assinale, utilizando as escalas apresentadas (de freqüência ou importância de uso) o item que melhor represente a sua realidade e, para a terceira questão, registre sua opinião a respeito da contribuição da disciplina no seu trabalho.

As informações fornecidas por você serão tratadas de forma agrupada e em conjunto com outros dados obtidos junto aos demais participantes do curso oferecido por esta organização, de modo a assegurar a confidencialidade das respostas individuais. É indispensável que todos os itens sejam respondidos. 
Com referência ao conteúdo abordado na disciplina "Introdução à Gestão do Ensino Superior" -30 horas.

1 - Assinale a freqüência com que você utiliza no trabalho cada um dos conteúdos ministrados ou assinale na coluna correspondente caso o mesmo não tenha sido abordado.

\begin{tabular}{|c|c|c|c|c|c|}
\hline 0 & 1 & 2 & 3 & 4 & 5 \\
\hline Nunca & Quase nunca & Às vezes & Quase sempre & Sempre & Não foi abordado \\
\hline
\end{tabular}

\begin{tabular}{|c|c|c|c|c|c|c|c|}
\hline & ITENS & 0 & 1 & 2 & 3 & 4 & 5 \\
\hline 1 & Conceitos e objetivos do serviço público & & & & & & \\
\hline 2 & Conceitos e objetivos do ensino superior público & & & & & & \\
\hline 3 & Evolução do sistema de ensino superior & & & & & & \\
\hline 4 & $\begin{array}{l}\text { Características das IES e das universidades brasileiras (criação, } \\
\text { concepção, missão, objetivos, política, finalidades) }\end{array}$ & & & & & & \\
\hline 5 & Políticas de funcionamento das IES: (desafios e perspectivas) & & & & & & \\
\hline 6 & IES na atualidade: (relevância, qualidade e internacionalização) & & & & & & \\
\hline
\end{tabular}

$2-$

\begin{tabular}{|l|c|c|c|c|}
\hline \multicolumn{1}{|c|}{ ITEM } & Nenhum & Pouco & Importante & $\begin{array}{c}\text { Muito } \\
\text { importante }\end{array}$ \\
\hline $\begin{array}{l}\text { Assinale o grau de importância do conteúdo } \\
\text { abordado nessa disciplina, para uma melhor } \\
\text { compreensão de sua realidade cotidiana. }\end{array}$ & & & & \\
\hline
\end{tabular}

3 - Escreva em poucas palavras como o conteúdo da disciplina "Introdução à Gestão do Ensino Superior" tem contribuído para o seu trabalho. 


\section{Com referência ao conteúdo abordado na disciplina "Gestão de Pessoas" - 45 horas.}

1 - Assinale a freqüência com que você utiliza no trabalho cada um dos conteúdos ministrados ou assinale na coluna correspondente caso o mesmo não tenha sido abordado.

\begin{tabular}{|c|c|c|c|c|c|}
\hline 0 & 1 & 2 & 3 & 4 & 5 \\
\hline Nunca & Quase nunca & Às vezes & Quase sempre & Sempre & Não foi abordado \\
\hline
\end{tabular}

\begin{tabular}{|c|c|c|c|c|c|c|c|}
\hline & ITENS & 0 & 1 & 2 & 3 & 4 & 5 \\
\hline 1 & Conceitos de gestão de pessoas, teorias e abordagens. & & & & & & \\
\hline 2 & Aspectos que influenciam os resultados organizacionais. & & & & & & \\
\hline 3 & Características que influenciam relações sindicais e trabalhistas. & & & & & & \\
\hline 4 & Características e análise de descrição de cargos, ergonomia e competências. & & & & & & \\
\hline 5 & Conceitos de recrutamento, seleção e suas características. & & & & & & \\
\hline 6 & Processo de gestão de desempenho. & & & & & & \\
\hline 7 & Gestão do conhecimento e desenvolvimento humano. & & & & & & \\
\hline 8 & Conceitos de TD\&E. & & & & & & \\
\hline 9 & Características de remuneração e produtividade. & & & & & & \\
\hline 10 & Segurança, medicina do trabalho e saúde ocupacional. & & & & & & \\
\hline 11 & Características das instituições e sua responsabilidade social. & & & & & & \\
\hline
\end{tabular}

$2-$

0

12

3

\begin{tabular}{|c|c|c|c|c|}
\hline ITEM & Nenhum & Pouco & Importante & $\begin{array}{c}\text { Muito } \\
\text { importante }\end{array}$ \\
\hline $\begin{array}{l}\text { Assinale o grau de importância do conteúdo } \\
\text { abordado nessa disciplina, para uma melhor } \\
\text { compreensão de sua realidade cotidiana. }\end{array}$ & & & & \\
\hline
\end{tabular}

3 - Escreva em poucas palavras como o conteúdo da disciplina “Gestão de Pessoas" tem contribuído para o seu trabalho. 
Com referência ao conteúdo abordado na disciplina "Direito Aplicado ao Ensino Superior" -30 horas.

1 - Assinale a freqüência com que você utiliza no trabalho cada um dos conteúdos ministrados ou assinale na coluna correspondente caso o mesmo não tenha sido abordado.

\begin{tabular}{|c|c|c|c|c|c|}
\hline 0 & 1 & 2 & 3 & 4 & 5 \\
\hline Nunca & Quase nunca & Ás vezes & Quase sempre & Sempre & Não foi abordado \\
\hline
\end{tabular}

\begin{tabular}{|l|l|c|c|c|c|c|c|}
\hline \multicolumn{1}{|c|}{ ITENS } & \multicolumn{1}{|c|}{0} & 1 & 2 & 3 & 4 & 5 \\
\hline 1 & Constituição jurídica das universidades & & & & & & \\
\hline 2 & Normas e legislação vigente nas IES & & & & & & \\
\hline 3 & Constituição de 1988 & & & & & & \\
\hline 4 & Lei de Diretrizes e Bases & & & & & & \\
\hline 5 & Responsabilidade social da universidade & & & & & & \\
\hline 6 & Visão multidisciplinar das IES & & & \\
\hline
\end{tabular}

$2-$

0 1

2 3

\begin{tabular}{|c|c|c|c|c|}
\hline \multicolumn{1}{|c|}{ ITEM } & Nenhum & Pouco & Importante & $\begin{array}{c}\text { Muito } \\
\text { importante }\end{array}$ \\
\hline $\begin{array}{l}\text { Assinale o grau de importância do conteúdo } \\
\text { abordado nessa disciplina, para uma melhor } \\
\text { compreensão de sua realidade cotidiana. }\end{array}$ & & & & \\
\hline
\end{tabular}

3 - Escreva em poucas palavras como o conteúdo da disciplina "Direito Aplicado ao Ensino Superior" tem contribuído para o seu trabalho. 


\section{Com referência ao conteúdo abordado na disciplina "Contabilidade Pública" - 45 horas.}

1 - Assinale a freqüência com que você utiliza no trabalho cada um dos conteúdos ministrados ou assinale na coluna correspondente caso o mesmo não tenha sido abordado.

\begin{tabular}{|c|c|c|c|c|c|}
\hline 0 & 1 & 2 & 3 & 4 & 5 \\
\hline Nunca & Quase nunca & Às vezes & Quase sempre & Sempre & Não foi abordado \\
\hline
\end{tabular}

\begin{tabular}{|c|c|c|c|c|c|c|c|}
\hline & ITENS & 0 & 1 & 2 & 3 & 4 & 5 \\
\hline 1 & $\begin{array}{l}\text { Aspectos introdutórios da teoria da contabilidade (objetivos, ativo, } \\
\text { passivo, receita, despesa, patrimônio, regime de caixa x regime de } \\
\text { competência) }\end{array}$ & & & & & & \\
\hline 2 & $\begin{array}{l}\text { Processo orçamentário (elaboração da proposta, discussão, votação e } \\
\text { aprovação da lei orçamentária, execução, controle e sua avaliação) }\end{array}$ & & & & & & \\
\hline 3 & $\begin{array}{l}\text { Execução orçamentária: } \\
\text { a) despesas (programação de desembolso, licitação, empenho, } \\
\text { liquidação, pagamento, divida ativa, restos a pagar) }\end{array}$ & & & & & & \\
\hline & b) receitas (lançamento, arrecadação e recolhimento) & & & & & & \\
\hline \multirow[t]{3}{*}{4} & $\begin{array}{l}\text { Características da contabilidade pública: } \\
\text { a) breve histórico, plano de contas e tabela de eventos }\end{array}$ & & & & & & \\
\hline & $\begin{array}{l}\text { b) sistemas: (financeiro, patrimonial, orçamentário, de } \\
\text { compensação, lançamentos, demonstrações contábeis) }\end{array}$ & & & & & & \\
\hline & $\begin{array}{l}\text { c) elaboração e análise, procedimentos e demonstrações previstas } \\
\text { na Lei de Responsabilidade Fiscal }\end{array}$ & & & & & & \\
\hline 5 & Normas internacionais de contabilidade no setor público & & & & & & \\
\hline
\end{tabular}

$2-$

0

12

$2-3$

\begin{tabular}{|c|c|c|c|c|}
\hline \multicolumn{1}{|c|}{ ITEM } & Nenhum & Pouco & Importante & $\begin{array}{c}\text { Muito } \\
\text { importante }\end{array}$ \\
\hline $\begin{array}{l}\text { Assinale o grau de importância do conteúdo } \\
\text { abordado nessa disciplina, para uma melhor } \\
\text { compreensão de sua realidade cotidiana. }\end{array}$ & & & & \\
\hline
\end{tabular}

3 - Escreva em poucas palavras como o conteúdo da disciplina "Contabilidade Pública" tem contribuído para o seu trabalho. 
Com referência ao conteúdo abordado na disciplina "Planejamento, Administracão e Gestão" - 45 horas.

1 - Assinale a freqüência com que você utiliza no trabalho cada um dos conteúdos ministrados ou assinale na coluna correspondente caso o mesmo não tenha sido abordado.

\begin{tabular}{|c|c|c|c|c|c|}
\hline 0 & 1 & 2 & 3 & 4 & 5 \\
\hline Nunca & Quase nunca & Ás vezes & Quase sempre & Sempre & Não foi abordado \\
\hline
\end{tabular}

\begin{tabular}{|c|c|c|c|c|c|c|c|}
\hline & ITENS & 0 & 1 & 2 & 3 & 4 & 5 \\
\hline 1 & Fundamentos e evolução das teorias da administração & & & & & & \\
\hline 2 & Funções da administração (planejar, organizar, dirigir e controlar) & & & & & & \\
\hline 3 & Responsabilidade social e ética nas organizações & & & & & & \\
\hline 4 & Conceitos de organização formal e informal & & & & & & \\
\hline 5 & $\begin{array}{l}\text { Processo de tomada de decisão (tipos, processo e condição para } \\
\text { tomada de decisão, ferramenta e decisão grupal). }\end{array}$ & & & & & & \\
\hline 6 & Planejamento (conceito, objetivos, níveis, vantagens e limitações) & & & & & & \\
\hline 7 & Estratégia (conceito, empresa x organização empresarial) & & & & & & \\
\hline 8 & $\begin{array}{l}\text { Planejamento e administração estratégica (visão, missão, valores e } \\
\text { objetivos) }\end{array}$ & & & & & & \\
\hline
\end{tabular}

$2-$

\begin{tabular}{|c|c|c|c|c|}
\hline \multicolumn{1}{|c|}{ ITEM } & Nenhum & Pouco & Importante & $\begin{array}{c}\text { Muito } \\
\text { importante }\end{array}$ \\
\hline $\begin{array}{l}\text { Assinale o grau de importância do conteúdo } \\
\text { abordado nessa disciplina, para uma melhor } \\
\text { compreensão de sua realidade cotidiana. }\end{array}$ & & & & \\
\hline
\end{tabular}

3 - Escreva em poucas palavras como o conteúdo da disciplina "Planejamento, Administração e Gestão" tem contribuído para o seu trabalho. 


\section{Com referência ao conteúdo abordado na disciplina "Trabalho, Gestão e Subjetividade nas Organizaç̃̃es". - 45 horas.}

1 - Assinale a freqüência com que você utiliza no trabalho cada um dos conteúdos ministrados ou assinale na coluna correspondente caso o mesmo não tenha sido abordado.

\begin{tabular}{|c|c|c|c|c|c|}
\hline 0 & 1 & 2 & 3 & 4 & 5 \\
\hline Nunca & Quase nunca & Às vezes & Quase sempre & Sempre & Não foi abordado \\
\hline
\end{tabular}

\begin{tabular}{|c|c|c|c|c|c|c|c|}
\hline & ITENS & 0 & 1 & 2 & 3 & 4 & 5 \\
\hline 1 & O trabalho no setor público a partir do modelo pós-burocrático & & & & & & \\
\hline 2 & Modelos de gestão e o indivíduo & & & & & & \\
\hline 3 & Gestão de qualidade total e sua relação com RH & & & & & & \\
\hline 4 & Comunicação nas organizações & & & & & & \\
\hline 5 & Qualidade e excelência no atendimento aos clientes & & & & & & \\
\hline 6 & Cultura organizacional & & & & & & \\
\hline 7 & Relações de poder e subjetividade dos indivíduos nas organizações & & & & & & \\
\hline 8 & Sofrimento humano no trabalho & & & & & & \\
\hline 9 & Os sentidos do trabalho & & & & & & \\
\hline
\end{tabular}

$2-$

\begin{tabular}{|c|c|c|c|c|}
\hline \multicolumn{1}{|c|}{ ITEM } & Nenhum & Pouco & Importante & $\begin{array}{c}\text { Muito } \\
\text { importante }\end{array}$ \\
\hline $\begin{array}{l}\text { Assinale o grau de importância do conteúdo } \\
\text { abordado nessa disciplina, para uma melhor } \\
\text { compreensão de sua realidade cotidiana. }\end{array}$ & & & & \\
\hline
\end{tabular}

3 - Escreva em poucas palavras como o conteúdo da disciplina "Trabalho, Gestão e Subjetividade nas Organizações" tem contribuído para o seu trabalho. 
Com referência ao conteúdo abordado na disciplina "Gestão Financeira Aplicada." - 30 horas.

1 - Assinale a freqüência com que você utiliza no trabalho cada um dos conteúdos ministrados ou assinale na coluna correspondente caso o mesmo não tenha sido abordado.

\begin{tabular}{|c|c|c|c|c|c|}
\hline 0 & 1 & 2 & 3 & 4 & 5 \\
\hline Nunca & Quase nunca & Às vezes & Quase sempre & Sempre & Não foi abordado \\
\hline
\end{tabular}

\begin{tabular}{|c|c|c|c|c|c|c|c|}
\hline & ITENS & 0 & 1 & 2 & 3 & 4 & \\
\hline 1 & Princípios fundamentais de finanças & & & & & & \\
\hline 2 & Valor do dinheiro no tempo & & & & & & \\
\hline 3 & $\begin{array}{l}\text { Conceitos e características de taxas de juros, risco e retorno, custos e } \\
\text { liquidez }\end{array}$ & & & & & & \\
\hline 4 & Benefício da educação: custo do aluno e custo do setor público & & & & & & \\
\hline 5 & Características de finanças comportamentais & & & & & & \\
\hline 6 & Importância do conhecimento da matemática financeira & & & & & & \\
\hline 7 & O poder da economia e o risco de um país & & & & & & \\
\hline 8 & $\begin{array}{l}\text { Contabilidade de custo: conceitos, alocação, regime de caixa e } \\
\text { competência }\end{array}$ & & & & & & \\
\hline 9 & Características da economia da informação & & & & & & \\
\hline
\end{tabular}

$2-$

0

\begin{tabular}{|l|l|l|l|c|}
\hline \multicolumn{1}{|c|}{ ITEM } & Nenhum & Pouco & Importante & $\begin{array}{c}\text { Muito } \\
\text { importante }\end{array}$ \\
\hline $\begin{array}{l}\text { Assinale o grau de importância do conteúdo } \\
\text { abordado nessa disciplina, para uma melhor } \\
\text { compreensão de sua realidade cotidiana. }\end{array}$ & & & & \\
\hline
\end{tabular}

3 - Escreva em poucas palavras como o conteúdo da disciplina “Gestão Financeira Aplicada" tem contribuído para o seu trabalho. 
Com referência ao conteúdo abordado na disciplina "Comportamento Organizacional" $\underline{\text { 30 horas. }}$

1 - Assinale a freqüência com que você utiliza no trabalho cada um dos conteúdos ministrados ou assinale na coluna correspondente caso o mesmo não tenha sido abordado.

\begin{tabular}{|c|c|c|c|c|c|}
\hline 0 & 1 & 2 & 3 & 4 & 5 \\
\hline Nunca & Quase nunca & Ás vezes & Quase sempre & Sempre & Não foi abordado \\
\hline
\end{tabular}

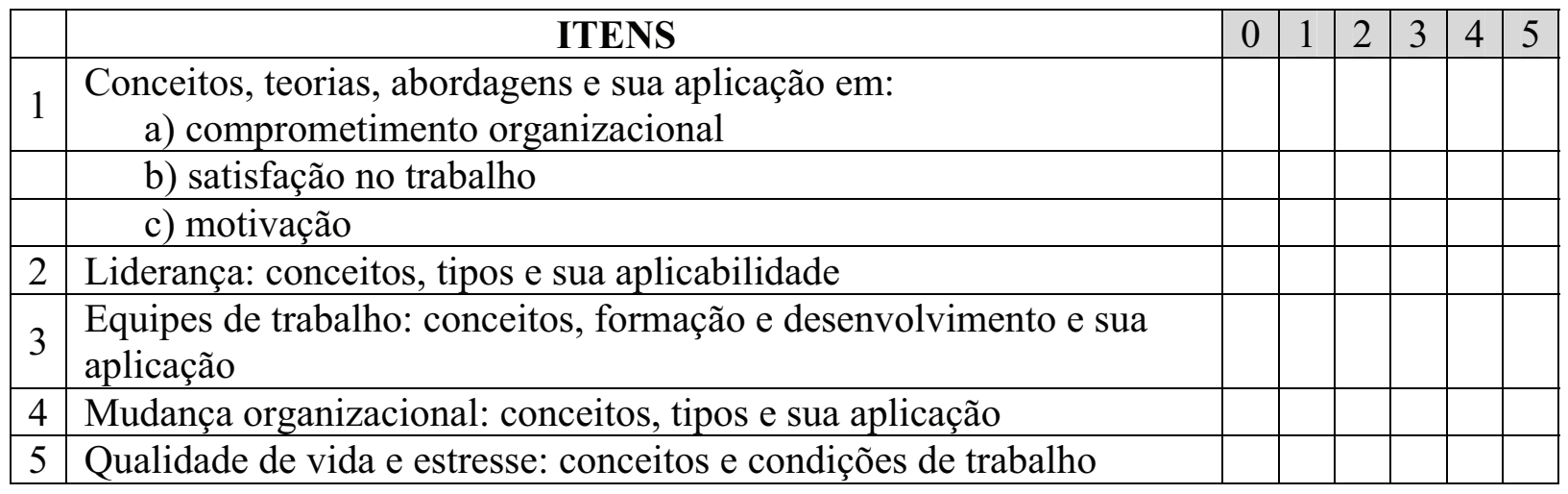

$2-$

\begin{tabular}{|c|c|c|c|c|}
\hline \multicolumn{1}{|c|}{ ITEM } & Nenhum & Pouco & Importante & $\begin{array}{c}\text { Muito } \\
\text { importante }\end{array}$ \\
\hline $\begin{array}{l}\text { Assinale o grau de importância do conteúdo } \\
\text { abordado nessa disciplina, para uma melhor } \\
\text { compreensão de sua realidade cotidiana. }\end{array}$ & & & & \\
\hline
\end{tabular}

3 - Escreva em poucas palavras como o conteúdo da disciplina “Comportamento Organizacional" tem contribuído para o seu trabalho. 
Com referência ao conteúdo abordado na disciplina "Direito Administrativo Aplicado" $\underline{\text { 30 horas. }}$

1 - Assinale a freqüência com que você utiliza no trabalho cada um dos conteúdos ministrados ou assinale na coluna correspondente caso o mesmo não tenha sido abordado.

\begin{tabular}{|c|c|c|c|c|c|}
\hline 0 & 1 & 2 & 3 & 4 & 5 \\
\hline Nunca & Quase nunca & Ás vezes & Quase sempre & Sempre & Não foi abordado \\
\hline
\end{tabular}

\begin{tabular}{|c|c|c|c|c|c|c|c|}
\hline & ITENS & 0 & 1 & 2 & 3 & 4 & 5 \\
\hline 1 & Direito administrativo: conceitos, função, objeto e princípios & & & & & & \\
\hline 2 & Poderes do Estado, Governo e Administração & & & & & & \\
\hline 3 & Características e princípios da administração pública e privada & & & & & & \\
\hline 4 & $\begin{array}{l}\text { Características das entidades políticas, administrativas, órgãos e } \\
\text { agentes públicos }\end{array}$ & & & & & & \\
\hline 5 & Poderes e deveres da administração pública & & & & & & \\
\hline 6 & $\begin{array}{l}\text { Ato administrativo: conceitos, requisitos, atributos, anulação, } \\
\text { revogação, vinculação e discricionariedade }\end{array}$ & & & & & & \\
\hline 7 & Licitação: conceitos, tipos e finalidade & & & & & & \\
\hline 8 & Contrato administrativo: conceitos e características & & & & & & \\
\hline 9 & Princípios e características do regime jurídico & & & & & & \\
\hline
\end{tabular}

$2-$

0

1

2

3

\begin{tabular}{|l|l|l|l|l|}
\hline ITEM & Nenhum & Pouco & Importante & $\begin{array}{c}\text { Muito } \\
\text { importante }\end{array}$ \\
\hline $\begin{array}{l}\text { Assinale o grau de importância do conteúdo } \\
\text { abordado nessa disciplina, para uma melhor } \\
\text { compreensão de sua realidade cotidiana. }\end{array}$ & & & & \\
\hline
\end{tabular}

3 - Escreva em poucas palavras como o conteúdo da disciplina "Direito Administrativo Aplicado" tem contribuído para o seu trabalho. 


\section{Com referência ao conteúdo abordado na disciplina "Métodos e Técnicas de Pesquisa em Organizaç̃es" - 30 horas.}

1 - Assinale a freqüência com que você utiliza no trabalho cada um dos conteúdos ministrados ou assinale na coluna correspondente caso o mesmo não tenha sido abordado.

\begin{tabular}{|c|c|c|c|c|c|}
\hline 0 & 1 & 2 & 3 & 4 & 5 \\
\hline Nunca & Quase nunca & Às vezes & Quase sempre & Sempre & Não foi abordado \\
\hline
\end{tabular}

\begin{tabular}{|c|c|c|c|c|c|c|c|c|}
\hline & ITENS & 0 & 1 & 2 & 3 & 4 & & 5 \\
\hline 1 & Características da ciência, do trabalho e da pesquisa científica. & & & & & & & \\
\hline 2 & Normas para elaboração de um trabalho científico. & & & & & & & \\
\hline 3 & Pesquisa científica: (características e classificações) & & & & & & & \\
\hline & a - pesquisa bibliográfica & & & & & & & \\
\hline & b- pesquisa quantitativa e qualitativa. & & & & & & & \\
\hline & $\begin{array}{l}\text { c- tipos de pesquisa e objetivos (survey, entrevista, focus group e } \\
\text { pesquisa documental). }\end{array}$ & & & & & & & \\
\hline 4 & Elaboração do projeto de pesquisa. & & & & & & & \\
\hline 5 & Desenvolvimento de pesquisa. & & & & & & & \\
\hline 6 & Elaboração da monografia. & & & & & & & \\
\hline
\end{tabular}

$2-$

\begin{tabular}{|l|c|c|c|c|}
\hline \multicolumn{1}{|c|}{ ITEM } & Nenhum & Pouco & Importante & $\begin{array}{c}\text { Muito } \\
\text { importante }\end{array}$ \\
\hline $\begin{array}{l}\text { Assinale o grau de importância do conteúdo } \\
\text { abordado nessa disciplina, para uma melhor } \\
\text { compreensão de sua realidade cotidiana. }\end{array}$ & & & & \\
\hline
\end{tabular}

3 - Escreva em poucas palavras como o conteúdo da disciplina "Métodos e Técnicas de Pesquisa em Organizações" tem contribuído para o seu trabalho. 
Para que possamos analisar as respostas dadas e a relação com o seu trabalho, pedimos a seguir algumas informações funcionais.

Há quanto tempo você trabalha na UnB?

Você tem subordinados?

( ) Não ( ) Sim - Quantos:

O trabalho que realiza se caracteriza por ser:

$0-(\quad$ ) atividade de apoio em unidade acadêmica da UnB

1 - ( ) atividade de apoio em unidade administrativa da UnB

$3-(\quad)$ outros. Quais?

Há quanto tempo trabalha nessa área?

Qual a sua idade?

Caso tenha mais alguma informação que gostaria de compartilhar conosco, por favor, escreva a seguir:

Obrigada por sua colaboração. 